\title{
REVIEW
}

\author{
ANXIOLYTIKA PŘÍRODNÍHO PU゚VODU II \\ Exotické rostliny \\ Anxiolytics of natural origin II \\ Exotic plants
}

\section{Zdeňka Navrátilová}

Univerzita Karlova v Praze, Př́rodovědecká fakulta , katedra botaniky

\begin{abstract}
Summary
The article presented here is being published next to the previous article Anxiolytics of natural Origin I, which discussed plants originally occurring in the Czech Republic and plants cultivated othere. The second part summarizes knowledge concerning plants, which are neither original nor commonly cultivated in the Czech Republic. These are the species as follows: Atractylodes macrocephala, Bacopa monnieri, Centella asiatica, Citrus spp., Clitoria ternatea, Echium amoenum, Erythrina mulungu, Morinda citrifolia, Myristica fragrans, Ocimum sanctum, Panax spp., Passiflora incarnata, Piper methysticum, Sceletium tortuosum, Withania somnifera, Zingiber officinale and Ziziphus jujuba. These plants have been used in traditional medicine in areas of their original occurrence for the treatment of different disorders including anxiety and sleeplessness. These plants are currently subjected to a number of scientific studies, which frequently support the presence of medicinal effects. In some of these plants, only preliminary results are available and further research is needed including preclinical studies in animals and subsequently clinical trials. A further research of active substances of these plants and mechanism of their action on the organism can result in the development of new products for the treatment of anxiety disorders and further mental diseases. Mental problems currently widely occur in the population and thus, the research is promising. In tropical and sparingly explored regions, there are definitely a number of further plants with anxiolytic and sedative effects and thus, further ethno-botanical and ethno-pharmacological research of plants employed in traditional medicine in these regions is of importance. The protection of biodiversity, particularly in tropical rainforest inhabited by many plants and animals, which can serve as a source of still unknown biologically active substances is also of a great importance.
\end{abstract}

Key words: anxiety disorders - anxiolytics - herbal remedy - traditional medicine

\section{Souhrn}

Tento článek navazuje na článek Anxiolytika prrírodního původu I, který se zabýval rostlinami původními v ČR a rostlinami zde pěstovanými. Druhá část shrnuje poznatky o rostlinách, které se v ČR nevyskytují ani běžně nepěstují. Jde o tyto druhy: Atractylodes macrocephala, Bacopa monnieri, Centella asiatica, Citrus spp., Clitoria ternatea, Echium amoenum, Erythrina mulungu, Morinda citrifolia, Myristica fragrans, Ocimum sanctum, Panax spp., Passiflora incarnata, Piper methysticum, Sceletium tortuosum, Withania somnifera, Zingiber officinale a Ziziphus jujuba. Tyto rostliny se používají v tradiční lidové medicíně $v$ oblastech původního výskytu $\mathrm{k}$ léčbě různých obtíží, mimo jiné úzkosti a nespavosti. $V$ současné době jsou tyto rostliny předmětem řady vědeckých studií a ty často tyto

Submitted: 2012-01-14 - Accepted: 2012-04-10 - Published online: 2012-06-22

KONTAKT: 14/2: 200-217 • ISSN 1212-4117 (Print) • ISSN 1804-7122 (Online) 
léčivé účinky potvrzují. U části rostlin jde pouze o předběžné výsledky a je potřeba další výzkum, a to jak studie na zvíratech, tak následně klinické studie. Další výzkum obsahových látek těchto rostlin a mechanismu jejich působení na organismus může vést $\mathrm{k}$ vývoji nových léčiv $\mathrm{k}$ léčbě úzkostných poruch i dalších psychických onemocnění. Psychické problémy jsou v současné době v populaci velmi rozšírené, proto je tento výzkum perspektivní. Zejména v tropických a málo prozkoumaných oblastech existuje jistě celá řada dalších rostlin s anxiolytickým a sedativním účinkem, důležitý je proto další etnobotanický a etnofarmakologický výzkum rostlin používaných v tradiční medicíně v těchto oblastech. Velmi důležitá je také ochrana biodiverzity, zejména tropických deštných lesů, kde žije mnoho rostlin i živočichů, kteří mohou být zdrojem dosud neznámých biologicky aktivních látek.

Klíčová slova: úzkostné poruchy - anxiolytika - bylinné přípravky - tradiční medicína

\section{Atractylodes macrocephala}

Atractylodes macrocephala Koidz. je jednoletá, 20-60 cm vysoká bylina z čeledi Asteraceae (hvězdnicovité). Lodyhy jsou od báze větvené, listy lysé, řapíkaté. Červené květy jsou uspořádány v úborech, plodem je nažka s chmýrem. Rostlina pochází ze severovýchodní Číny, pěstuje se po celém jejím území. Oddenky se využívají v tradiční čínské medicíně, používá se i další druh, Atractylodes lancea (Thunb.) DC. (Wu et al., 2011; Singhuber et al., 2012).

Oddenky A. macrocephala obsahují seskviterpenické laktony atractylenolid I, II a III, biatractylenolid, atractylosid A, polyacetyleny, taraxeryl acetát, $\beta$-sitosterol, stigmasterol a polysacharidy (Jiang et al., 2011; Singhuber et al., 2012). Nadzemní část obsahuje flavonoidy (apigenin, luteolin aj.), kumariny (7-hydroxykumarin), 2,6-dimethoxychinon a lupeol (Peng et al., 2011).

Oddenky se používají v tradiční čínské medicíně $\mathrm{k}$ léčbě zažívacích potíží, cukrovky, nespavosti, neklidu a úzkosti (Lin et al., 1997; Singhuber et al., 2012).

Studie na zvíratech potvrdily protizánětlivé, protinádorové a další účinky (Li et al., 2007; Dong et al., 2008; Jiang et al., 2011). Seskviterpenické laktony atractylenolid I, II a III působí jako allosterické modulátory GABA-A receptoru. Tyto účinky potvrzují tradiční využívání Atractylodes macrocephala k léčbě úzkosti (Singhuber et al., 2012).

\section{Bacopa monnieri}

Bacopa monnieri (L.) Wettst. syn. Herpestis monnieri Kunth (bakopa drobnolistá, brahmi) je nenápadná vytrvalá bylina z čeledi Scrophularia- ceae (krtičníkovité), nově je na základě molekulárních dat (Stevens, 2008) řazena do čeledi Plantaginaceae (jitrocelovité). Rostliny mají rozvětvené poléhavé či vystoupavé dužnaté lodyhy s drobnými přisedlými okrouhlými listy. Květy vyrůstají v úžlabí listů, jsou pětičetné, nafialovělé, modravé či bílé s tmavšími žilkami. Roste na vlhkých a podmáčených místech a na písčitých březích, někdy i ve vodě. Bacopa monnieri pochází z jihovýchodní Asie (Indie, Čína, Nepál, Vietnam, Srí Lanka, Tchaj-wan), pěstuje se i šírí jako plevel v mnoha dalších částech světa (Zhengyi a Raven, 1998; Gohil et al., 2010). Někdy se také pěstuje jako akvarijní rostlina (Rataj, 1983). K léčebným účelům se používá celá rostlina nebo její nadzemní část (Khare, 2007).

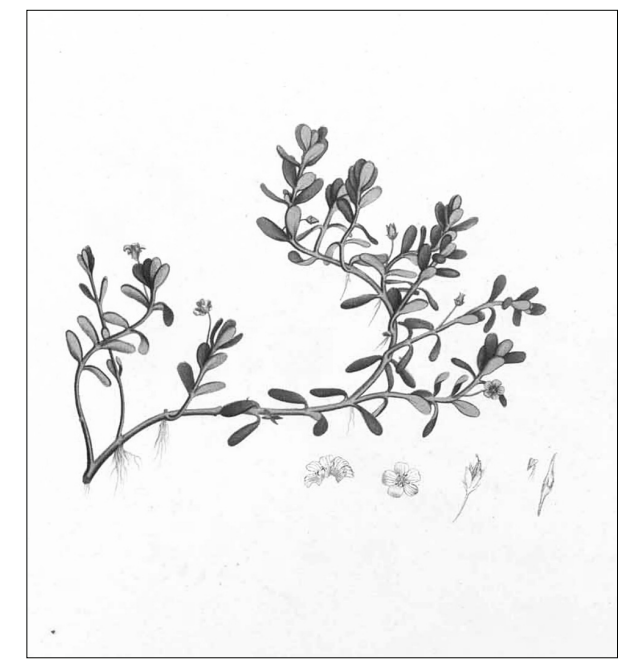

Bacopa monnieri je již po staletí (až 3000 let) využívána v tradiční ayurvédské medicíně, nej- 
častěji pod jménem brahmi. Někdy je však slovem brahmi označován také pupečník asijský (Centella asiatica), př́padně kombinace těchto dvou rostlin. Jméno brahmi je odvozeno ze sanskrtského slova bráhma, které označuje v hinduistickém náboženství boha, všudypřítomnou tvoŕivou sílu (Shikha et al., 2009; Gohil et al., 2010). Bakopa patří mezi tzv. medhyarasayana léky, tedy léky na zlepšení paměti a inteligence. Kromě toho je používána i k léčbě dalších onemocnění, a to pro svůj sedativní, antikonvulzivní, protizánětlivý, antipyretický a analgetický účinek (Shikha et al., 2009).

Bacopa monnieri obsahuje radu látek, z nichž nejdůležitější jsou triterpenické saponiny, alkaloidy a steroidní látky. Z alkaloidů jsou zastoupeny brahmin, nikotinin a herpestin, ze steroidů napr. stigmasterol a $\beta$-sitosterol (Shikha et al., 2009). Dále rostliny obsahují flavonoidy, např. apigenin a luteolin (Williamson, 2003).

Hlavními účinnými látkami jsou triterpenické saponiny dammaranového typu: bakosidy A, B a C a bakopasaponiny A, B, C a D. Aglykonem jsou bakogeniny 1, 2 a 3 a pseudojujubogenin. Dalšími látkami jsou hersaponin, monnierasidy a bakopasidy I-V (Shikha et al., 2009).

Obsahové látky Bacopa monnieri vykazují celou řadu účinků na organismus, středem pozornosti jsou zejména účinky na nervový systém. Ve studiích na lidech i na zvíratech bylo zjištěno zlepšení kognitivních funkcí po podávání extraktu z Bacopa monnieri (Stough et al., 2001; Morgan, Stevens, 2010; Charles et al., 2011). Zjištěn byl také antioxidační účinek a preventivní působení extraktu Bacopa monnieri proti neurotoxickému účinku hliníku u potkanů (Jyoti et al., 2007; Saraf et al., 2010), dále neuroprotektivní působení proti poškození neuronů $\beta$-amyloidem (Limpeanchob et al., 2008). Působí také jako scavenger volných radikálů a inhibuje lipoperoxidaci. I antioxidační a neuroprotektivní účinek přispívá $\mathrm{k}$ pozitivnímu vlivu na kognitivní funkce (Uabundit et al., 2010).

Zajímavý je také anxiolytický účinek, při podávání vyšších dávek je účinek srovnatelný s lorazepamem (Bhattacharya, Ghoshal, 1998; sec. Anonym, 2004). V dvojitě zaslepené, placebem kontrolované studii na 54 dobrovolnících starších 65 let došlo po podávání standardizovaného extraktu Bacopa monnieri ke zlepšení paměti a také ke zmírnění příznaků deprese a úz- kosti (Calabrese et al., 2008). V experimentech na zviŕatech (plovací test, test naučené bezmocnosti) byl zjištěn antidepresivní účinek srovnatelný s imipraminem (Sairam et al., 2002). Ve vyšších dávkách a při delším užívání má extrakt Bacopa monnieri také antikonvulzivní účinek (Gohil, Patel, 2010).

Registrována byla rada patentů na způsoby pŕípravy extraktu z Bacopa monnieri a na její využití $\mathrm{v}$ kombinaci $\mathrm{s}$ dalšími rostlinami (zejména Centella asiatica) k léčbě různých onemocnění, nap̌r. poruch paměti, únavy, deprese a ADHD (Shinomol et al., 2011). Je také možné, že objasnění mechanismu působení obsahových látek na organismus povede $\mathrm{k}$ vývoji nových léčiv (Sairam et al., 2002).

\section{Centella asiatica}

Centella asiatica (L.) Urb. syn. Hydrocotyle asiatica L. (pupečník asijský) je vytrvalá bylina z čeledi Apiaceae (miř́kovité), někdy je řazena do čeledi Mackinlayaceae. Rostliny mají plazivé lodyhy, listy s dlouhými řapíky a okrouhlou až ledvinitou čepelí, přisedlé květy s bíle či růžově zbarvenou korunou jsou uspořádány $\mathrm{v}$ jednoduchých okolících. Roste hojně na vlhkých místech, rozšírena je $\mathrm{v}$ tropických a subtropických oblastech celého světa, a to až do výšky 1900 m n. m. (Zhengyi, Raven, 2005). V Číně je Centella asiatica nazývána Gotukola, v Indii brahmi či manduukaparani. Jménem brahmi však bývá označována i Bacopa monnieri či směs těchto dvou rostlin. Rostlina se používá v tradiční medicíně a také jako zelenina (Zheng, Qin, 2007).

Hlavními účinnými látkami Centella asiatica jsou triterpenoidy, na základě jejich obsahu se posuzuje kvalita drogy. Rostliny obsahují pentacyklické triterpenické saponiny ursanového a oleananového typu: asiatová kys., asiatikosid, madecassová kys., madecassodid, brahmosid, brahmová kys., brahminosid, thankunisid, isothankunisid, centellosid, madasiatová kys., centová kys., cenellová kys., betulinová kys., indocentová kys. Dále rostliny obsahují flavonoidy (kvercetin, kaempferol, rutin, naringin), aromatické látky (caryophyllen, farnesol, elemen), polysacharidy, mastné kyseliny, seskviterpeny, alkaloidy, steroly a karotenoidy (Brinkhaus et al., 2000; Zheng, Qin, 2007; James, Dubery, 2009).

Centella asiatica vykazuje řadu léčivých účinků, díky kterým je široce používána $\mathrm{v}$ lidové medicíně ve východní Asii, a to k léčbě zánětů, 
astmatu, kožních problémů a vředů, průjmu, žaludečních vředů a také na zlepšení paměti (Zheng, Qin, 2007). Extrakt má také antioxidační, radioprotektivní, protinádorový, antibakteriální, antivirový a antidepresivní účinek, používá se i ke zlepšení kognitivních funkcí (Gohil et al., 2010; Shinomol et al., 2011).

Kromě těchto účinků má Centella asiatica také účinek anxiolytický. Ve studii se 33 pacienty trpícími generalizovanou úzkostnou poruchou došlo po podávání extraktu Centella asiatica ke zlepšení symptomů úzkosti a deprese (Jana et al., 2010). Ve studii na potkanech byl také potvrzen anxiolytický účinek (Wijeweera et al., 2006).

Centella asiatica se používá nejčastěji v kombinaci s Bacopa monnieri pod jménem brahmi, a to $\mathrm{k}$ léčbě poruch paměti, deprese a úzkosti. Registrována byla řada patentů (Shinomol et al., 2011).

\section{Citrus spp.}

Citrusy neboli citroníky (Citrus L.) jsou keře či malé stromky z čeledi Rutaceae, podčeled' Citroideae, které pocházejí z jižní a jihovýchodní Asie. Rostliny mají obvykle okrouhle vejčité listy a vonné bílé květy, které dozrávají v charakteristické plody. Plodem je zvláštní bobule, tzv. hesperidium, s dužninou tvořenou št'avnatými výrůstky plodolistů a s oplodím obsahujícím schizolysigenní nádržky se silicemi. Zevní vrstva oplodí (flavedo) obsahuje siličné nádržky, vnitřní vrstva (albedo) je tvořena parenchymem $\mathrm{s}$ velkými mezibuněčnými prostorami (van Wyk, Wink, 2005; Jahodář, 2006).

Rod Citrus nemá přehlednou klasifikaci, udává se 16-160 druhů. K nejznámějším patř́ Citrus limon (L.) Burm. f. (citroník), Citrus reticulata Blanco (mandarinka), Citrus $\times$ paradisi Macfad. (grapefruit), Citrus maxima (Burm.) Merr. (pomelo), Citrus sinensis (citroník čínský, pomerančovník) a Citrus aurantium L. (brigárdie, citroník pomerančový). Citrus aurantium obsahuje několik poddruhů, k nejdůležitějším patří $C$. aurantium ssp. amara (hořký pomeranč), C. aurantium ssp. aurantium (sladký pomeranč) a $C$. aurantium ssp. bergamia (bergamot) (Jahodář, 2006).

Z pomerančovníků se ve farmacii využívá sušené oplodí (Aurantii amari pericarpium a Aurantii pericarpium dulce), z listi̊, květů a oplodí se pak získává silice (Aurantii dulcis aetheroleum a Bergamottae aetheroleum). Tyto drogy se použí- vají zejména jako korigencia chuti a vůně u nepříjemně chutnajících léčiv. Zjištěny byly i některé léčivé účinky, např. stimulace chuti k jídlu a sedativní účinky (Bruneton, 1999; Jahodář, 2006). V Českém lékopisu 2009 jsou uvedeny tyto drogy: Aurantii amari floris aetheroleum, Aurantii amari flos, Aurantii amari pericarpii tinctura, Aurantii amari pericarpium a Aurantii dulcis pericarpii aetheroleum (kolektiv autorů, 2009).

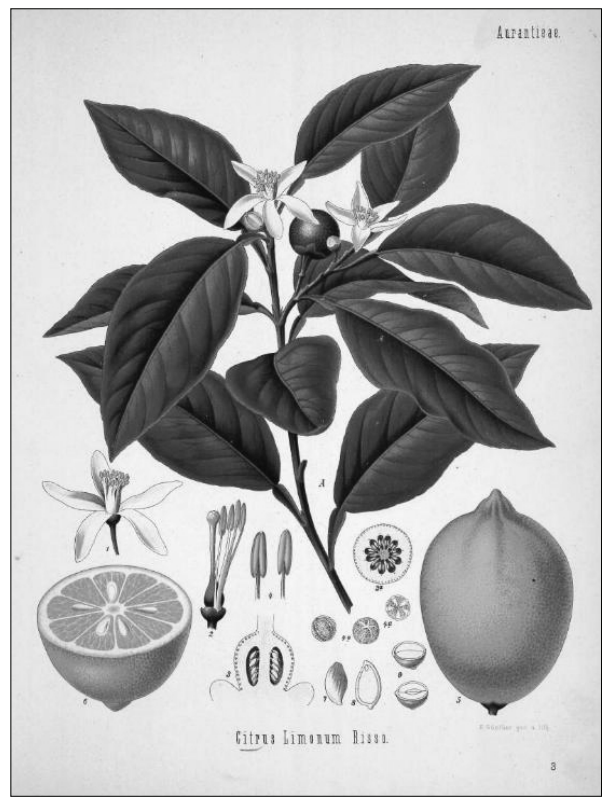

Silice $\mathrm{z}$ různých druhů a také $\mathrm{z}$ různých částí rostlin se liší zastoupením jednotlivých obsahových látek a jejich poměrem. Silice z oplodí pomerančovníku obsahuje zejména monoterpenoidy (limonen, $\beta$-myrcen), aldehydy (ketanal, citraly neral a geranial) a linalool. Silice $z$ květů pomerančovníku obsahuje linalool, linalyl acetát, limonen, $\alpha$-pinen, $\beta$-pinen, geranyl acetát a neryl acetát (Bruneton, 1999). Silice z citroníku obsahuje monoterpenoidy a seskviterpenoidy (limonen, linalool, limonen, citronellal, neral, geranial a geranylacetát) a flavonoidy naringenin a hesperidin (van Wyk, Wink, 2005; Lopes Campêlo et al., 2011).

Citrusy se tradičně používají k léčbě poruch zažívání, úzkosti a nespavosti. Śt'áva z citronů se využívá jako zdroj vitaminu $\mathrm{C}$, $\mathrm{k}$ léčbě bolesti v krku a kožních problémů (van Wyk, Wink, 2005). Silice se používá v aromaterapii $\mathrm{k}$ léčbě úzkosti (Faturi et al., 2010).

$\mathrm{V}$ experimentu na potkanech byla zvíratům p. o. podávána silice z pomerančovníku, zazna- 
menán byl anxiolytický účinek a prodloužení narkotického účinku pentobarbitalu. Tyto výsledky potvrzují používání $\mathrm{v}$ tradiční medicíně (Carvalho-Freitas, Costa, 2002).

$\mathrm{V}$ experimentu na potkanech byla zviŕata vystavena působení silice ze sladkého pomeranče, efekt byl srovnáván se silicí z australského čajovníku (tea tree) neboli kajeputu strrídavolistého (Melaleuca alternifolia) jako negativní kontrolou. Silice z pomerančovníku vykazovala oproti kontrole signifikantní anxiolytický účinek. Tyto výsledky podporují využívání citrusových silic $\mathrm{v}$ aromaterapii k léčbě úzkosti (Faturi et al., 2010).

$\mathrm{V}$ experimentu na myších byla zvíratům $\mathrm{p}$. o. podávána silice $\mathrm{z}$ listů citroníku, $\mathrm{v}$ různých modelech vykazoval extrakt anxiolytický a sedativní účinek, který je pravděpodobně vyvolán ovlivněním benzodiazepinových GABAergních receptorů, a také účinek antidepresivní, způsobený ovlivněním noradrenergní a serotonergní transmise v mozku. Účinek byl antagonizován působením reserpinu (Lopes Campêlo et al., 2011).

$\mathrm{V}$ experimentu na potkanech byla zvírata vystavena působení bergamotové silice, jako standard byl použit diazepam. Diazepam i silice vykazovaly anxiolytický účinek, snižovaly hladinu kortikosteronu v krvi a zvyšovaly hladinu GABA v hipokampu (Saiyudthong, Marsden, 2011).

Ve studii na 72 lidech bylo 35 pacientů před návštěvou zubního lékaře vystaveno působení silice z pomerančovníku, 37 pacientů sloužilo jako kontrolní skupina. U pacientů vystavených působení silice bylo oproti kontrolní skupině popisováno snížení úzkosti, zklidnění a zlepšení nálady (Lehrner et al., 2000).

\section{Clitoria ternatea}

Clitoria ternatea L. (klitoria ternatská) je vytrvalá bylina z čeledi Fabaceae (bobovité). Rostliny jsou vždyzelené, mají popínavé lodyhy až $3 \mathrm{~m}$ dlouhé a nápadné $2-4 \mathrm{~cm}$ velké květy. Květy jsou modré se žlutým středem nebo bílé. Latinské jméno Clitoria pochází z toho, že květy mají svým tvarem připomínat ženské pohlavní orgány. Plodem jsou lusky. Rostlina pochází z Moluckých ostrovů (ostrov Ternate), často se pěstuje jako okrasná nebo léčivá rostlina (Jain et al., 2003).

Rostlina obsahuje flavonoidy a jejich glykosidy (kvercetin, myricetin, kaempferol), antokyany (delphinidin, malvidin, cyanidin), taxaxerol a taxaxeron, p-hydroxyskořicovou kyselinu, hexacosanol, aparajitin a $\beta$-sitosterol. Dále rostliny obsahují proteiny s antifungálním účinkem, které slouží jako ochrana proti houbovým chorobám (Jain et al., 2003; Patil, Patil, 2011). Semena mají vysoký obsah proteinů, dále obsahují mastné kyseliny (palmitovou, stearovou, olejovou, linoleovou a linolenovou) a $\beta$-sitosterol (Taur, Patil, 2011).

Kořeny, listy a semena Clitoria ternatea se používají v tradiční ayurvédské medicíně $\mathrm{k}$ léčbě řady obtíží. Kořeny se používají k léčbě psychických onemocnění, demence, migrény, lepry, kožních zánětů, horečky, epilepsie, astmatu, bronchitidy a tuberkulózy. Listy se používají $\mathrm{k}$ léčbě jaterních onemocnění a bolestí uší, semena mají laxativní účinek (Jain et al., 2003; Patil, Patil, 2011).

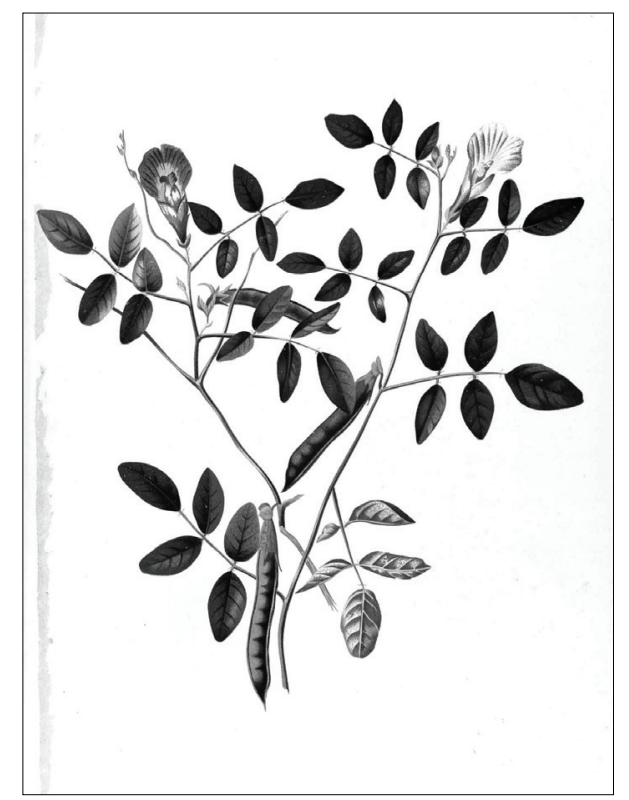

V experimentech na zvíratech bylo zaznamenáno zlepšení paměti po podávání extraktu Clitoria ternatea. Př́i podávání potkanům došlo ke zmírnění amnézie způsobené elektrošokovou terapií. Extrakt pravděpodobně ovlivňuje aktivitu acetylcholinesterázy a zvyšuje koncentraci acetylcholinu v mozku (Taranalli, Cheeramkuczhi, 2000).

$\mathrm{V}$ experimentu na myších byl na různých animálních modelech zkoumán anxiolytický, antikonvulzivní a nootropní účinek. Dále bylo studováno ovlivnění dopaminergní, serotonergní, noradrenergní a cholinergní transmise v mozku pomocí haloperidolu, lithia, klonidinu a dusnanu sodného. Ve studii se potvrdila řada účinků na centrální nervový systém - anxiolytický, pro- 
tistresový, antikonvulzivní, antidepresivní a nootropní. Objasnění mechanismu účinku je důležité pro pŕípadnou léčbu lidí extraktem Clitoria ternatea $\mathrm{v}$ budoucnosti (Jain et al., 2003).

\section{Echium amoenum}

Echium amoenum Fisch. \& C.A. Mey. (hadinec, druhové české jméno nemá) je jednoletá, dvouletá nebo vytrvalá bylina s modrofialovými květy, patři do čeledi Boraginaceae (brutnákovité). Roste v horách v severní části Íránu, kde je používán $\mathrm{v}$ tradiční medicíně $\mathrm{k}$ léčbě řady obtíží. Pěstuje se také jako okrasná rostlina (Mehrabani et al., 2005; Sayyah et al., 2006).

Rostlina obsahuje fenolické látky, především kyselinu rozmarýnovou, 0,05 \% silice (hlavní složkou je $\delta$-kadinen), flavonoidy, saponiny, terpenoidy, steroly a alkaloidy (Ghassemi et al., 2003; Mehrabani et al., 2005; Sayyah et al., 2006).

Extrakt z květů vykazuje analgetický, protizánětlivý, antibakteriální, antioxidační, antikonvulzivní, anxiolytický a sedativní účinek. Rostlina se tradičně používá $\mathrm{k}$ léčbě kašle, bolesti v krku a zápalu plic (Gholamzadeh et al., 2007; Sayyah et al., 2009).

$\mathrm{V}$ experimentu na potkanech a myších byl zjištěn anxiolytický účinek extraktu z květů Echium amoenum (Rabbani et al., 2004; Gholamzadeh et al., 2007). V další studii na myších byl také potvrzen anxiolytický účinek extraktu Echium amoenum, při užívání nevznikla tolerance (Rabbani et al., 2011).

V dvojitě slepé, placebem kontrolované studii byl zjištěn antidepresivní účinek prri léčbě lehké až středně těžké deprese (Sayyah et al., 2006). Zkoumán byl také účinek extraktu při léčbě obsedantně-kompulzivní poruchy (OCD). Předběžné výsledky naznačují, že Echium amoenum je prri léčbě OCD účinnější než placebo. Potřeba jsou ale další studie (Sayyah et al., 2009).

\section{Erythrina mulungu}

Erythrina mulungu Mart. ex Benth. (zarděnice mulungu, korálový strom) je strom pocházející z Jižní Ameriky, patř́ do čeledi Fabaceae (bobovité). Stromy jsou až 10 m vysoké, kvetou výraznými červenými květy (latinské jméno Erythrina pochází z řeckého slova erythros = červený). K léčebným účelům se používá především drcená kůra, známá je pod domorodým jménem mulungu (Patočka, 2009).
Kůra mulungu obsahuje radu biologicky aktivních látek, nejvýznamnější jsou tetrahydroisochinolinové alkaloidy. Základem struktury je erythrinan, látky jsou známy jako tzv. erythrinové alkaloidy. Z nejdůležitějších je to erysotrin, erythravin a erysopin. Dále rostliny obsahují flavonoidy (daidzein, phaseolin) a terpeny (Patočka, 2009).

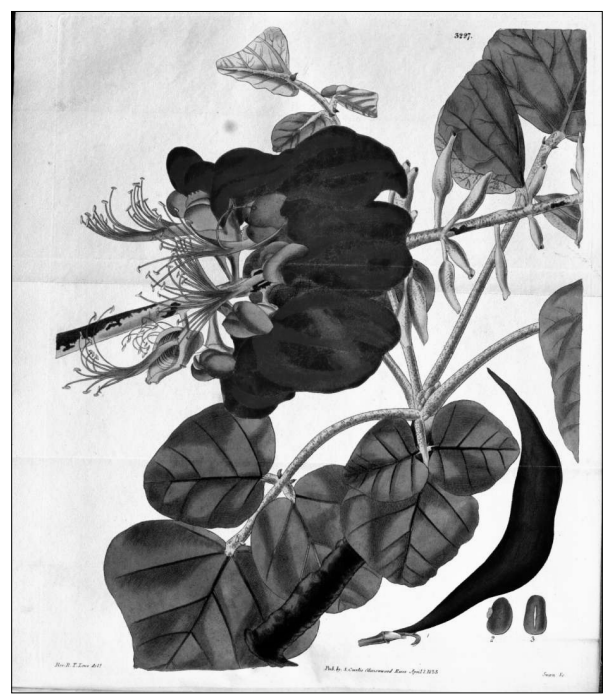

Erythrinové alkaloidy mají anxiolytické a antikonvulzivní účinky. Mechanismus účinku dosud není přesně znám, ale pravděpodobně je jiný než u benzodiazepinů. Alkaloidy aktivují GABA-A receptory a muskarinové acetylcholinové receptory, zvyšují uvolňování acetycholinu, zvyšují propustnost membrány pro $\mathrm{Ca}^{2+}$ ionty a uvolňují vápník z intracelulárních zásob (Carvalho et al., 2009).

Alkaloidy mají i řadu dalších účinků: analgetický, antidepresivní, protizánětlivý, spasmolytický, baktericidní, hepatoprotektivní, hypotenzivní a diuretický. V Jižní Americe se použivá k léčbě astmatu, úzkosti, zánětů a infekcí, křečí, kašle, epilepsie, revmatismu, horečky a bolesti (Duke, 2009).

V různých experimentálních modelech úzkosti byl u myší po podávání extraktu z květů $E$. mulungu zjištěn anxiolytický účinek. Za tento účinek pravděpodobně zodpovídá zejména erythravin a (+)-11- $\alpha$-hydroxyerythravin (Flausino et al., 2007).

$\mathrm{V}$ experimentu na potkanech byl po podávání extraktu z květenství E. mulungu zaznamenán anxiolytický účinek (Onusic et al., 2002). $\mathrm{V}$ dalším experimentu na potkanech byl po po- 
dávání extraktu z kůry Erythrina mulungu a E. velutina také zaznamenán anxiolytický účinek (Ribeiro et al., 2006).

Ve studii na myších byl zkoumán také antikonvulzivní účinek extraktu z kůry druhů Erythrina mulungu a Erythrina velutina. U strychninem vyvolaných křečí došlo po podávání 200 a $400 \mathrm{mg} / \mathrm{kg}$ extraktu ke snížení doby trvání křečí a oddálení smrti (Vasconcelos et al., 2007). Extrakt má také antinociceptivní účinek, a to nezávislý na opiodním systému (Vasconcelos et al., 2003).

Experimenty na zvíratech prokázaly, že Erythrina mulungu má anxiolytické účinky, a potvrdily tak tradiční využívání této rostliny. Dosud však nebyla realizována žádná klinická studie. $\mathrm{V}$ internetových obchodech je v prodeji drcená kůra mulungu.

\section{Morinda citrifolia}

Morinda citrifolia L. je tropický keř či malý strom z čeledi Rubiaceae (mořenovité). Rostliny jsou vždyzelené, mají široké vstřícné listy a bílé květy, plodem je souplodí peckovic krémově bílé barvy. Známá je zejména pod tradičním havajským jménem noni, tím se označují i její

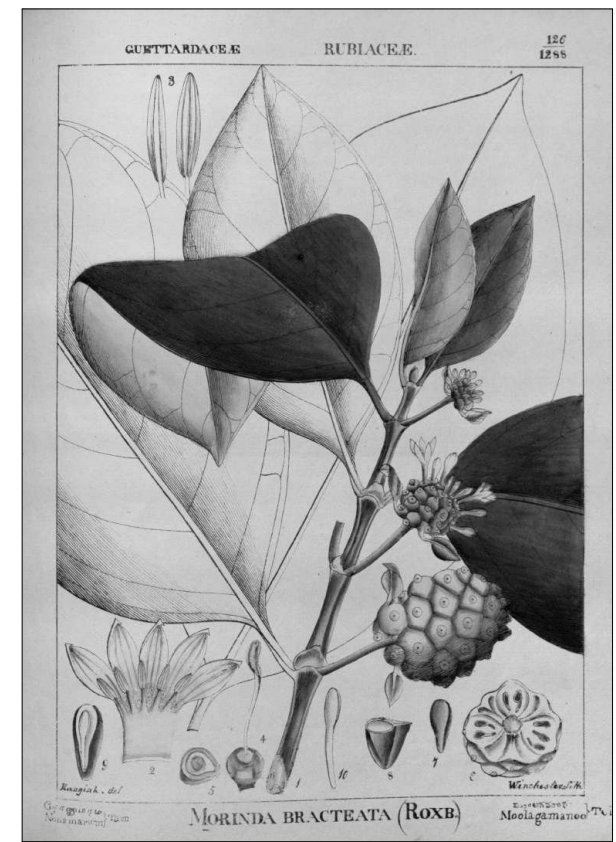

jedlé plody. Morinda citrifolia roste v nížinách v řídkých lesích či na mořském pobřeží v jihovýchodní Asii až v severní části Austrálie
(Vietnam, Čína, Malajsie, Srí Lanka, Indie, Filipíny). Introdukována byla do tropických částí Jižní Ameriky, Polynésie a karibské oblasti, kde se hojně pěstuje (Zhengyi et al., 2011).

Morinda citrifolia neboli noni obsahuje více než 160 různých látek. Zjištěny byly alkaloidy (xeronin), fenolické látky (anthrachinony damnacanthal, morindon, morindin aj.), dále aukubin, asperulosid a scopoletin, kys. ursolová, organické kyseliny (kaproová a kaprylová kys.), terpenoidy, steroidní látky ( $\beta$-sitosterol), lignany, flavonoidy, aminokyseliny, vitaminy a minerály (Chan-Blanco et al., 2006; Potterat, Hamburger, 2007).

Morinda citrifolia se tradičně použivá $\mathrm{k}$ léčbě řady onemocnění, např. cukrovky, artritidy, vysokého krevního tlaku, nádorových onemocnění, zažívacích potíží, žaludečních vředů, deprese, bolesti a žilních problémů (Wang et al., 2002). K léčebným účelům se používají všechny části rostliny - listy, plody, kořeny, kůra, květy i semena (Potterat, Hamburger, 2007).

$\mathrm{V}$ experimentech byly zjištěny účinky antibakteriální, antivirové, protinádorové, antihelmintické, analgetické, hypotenzivní a imunomodulační (Wang et al., 2002). Kromě těchto účinků má noni také účinky sedativní a anxiolytické. Mechanismem působení je ovlivnění GABAergní transmise v mozku, obsahové látky se váží na GABA-A receptory (Deng et al., 2007). Extrakt z plodů má také antidepresivní účinek, obsahové látky působí jako inhibitory monoaminoxidázy A a B (Deng, West, 2011).

$\mathrm{V}$ experimentu na myších měl lyofilizovaný extrakt z kořenů Morinda citrifolia analgetický a sedativní účinek. Analgetický účinek byl antagonizován naloxonem, který působí jako antagonista opioidních receptorů. Extrakt měl také sedativní účinky a prodlužoval anestetický účinek pentobarbitalu (Younos et al., 1990). $\mathrm{V}$ experimentu na potkanech vykazovala št’áva z plodů noni anxiolytický účinek (Kalandakanond et al., 2004 sec. Deng et al., 2007).

\section{Myristica fragrans}

Myristica fragrans L. (muškátovník pravý, macizeň pravá) je vždyzelený strom až 20 m vysoký, patř́i do čeledi Myristicaceae (muškátovníkovité). Listy jsou stř́idavé, vždyzelené, kožovité, květy pak drobné, nenápadné. Květy dozrávají ve světle žluté dužnaté peckovice, které za zralosti pukají ve 2-4 chlopně. Uvnitř plodu je velké jádro, které je na povrchu pokryté jasně červe- 
ným, po usušení žlutým míškem. Uvnitř jádra je pak šedohnědě zbarvené semeno. Pochází z jihovýchodní Asie (Molucké ostrovy, ostrov Amboine). Pěstuje se hlavně v Malajsii, Indonésii a Západní Indii (Polívka, 1908; van Wyk, Wink, 2005).

Sušená semena (Myristicae semen - muškátový „orríšek") a míšek (Myristicae arillus, M. macis muškátový „květ") se používají zejména jako koření, ale mají i léčivé a halucinogenní účinky. Ze semen se získává silice (Myristicae aetheroleum), která je lékopisná dle Českého lékopisu 2009 (kolektiv autorů, 2009). Semena a míšek obsahují cca $15 \%$ silice, hlavními složkami jsou sabinen, $\alpha$-pinen, $\beta$-pinen a myristicin, $v$ menším množství jsou zastoupeny elemicin, eugenol, isoeugenol, methyleugenol a safrol. Dále semena obsahují cca $75 \%$ mastných kyselin a různé lignany a isolignany (van Wyk, Wink, 2005).

Myristica fragrans má důležité postavení $\mathrm{v}$ tradiční indonéské medicíně, používá se k léčbě žaludečních potíží a křečí, ledvinových potíží, revmatismu, nervozity, zvracení a nachlazení. Na Moluckých ostrovech se používá jako sedativum pro děti, obvykle $\mathrm{v}$ nápoji z mléka či banánů. V Malajsii se používá jako tonikum $\mathrm{a}$ afrodisiakum a $\mathrm{k}$ léčbě malárie a bolestí hlavy, v Indii také jako součást betelového sousta (Rätsch, 2005). Potvrzen byl účinek antimikrobiální, spasmolytický a protizánětlivý (van Wyk, Wink, 2005).

Za psychoaktivní účinek zodpovídá myristicin, elemicin a safrol. Tyto sloučeniny se metabolicky transformují na amfetaminové deriváty, které vyvolávají ve vyšších dávkách halucinace a euforii. Legislativně je však muškátový oříšek považován za koření, nevztahují se na něj proto žádná omezení jako na drogy. Jde tedy o lehce a levně dostupnou drogu, její užívání ve větším množství však není bezpečné. Již 5-10 g ořišku může mít toxické účinky (Hallström, Thuvander, 1997). Muškátový orríšek má také dlouhý „dojezd“, symptomy otravy (nevolnost, sucho v ústech, žízeň, závratě, úzkost, neklid, malátnost) přetrvávají ještě 24-48 hodin (Demetriades et al., 2005; Krol, Janssen, 2010).

Zajímavé je, že přestože se muškátový oříšek tradičně používá $\mathrm{k}$ léčbě nervozity a nespavosti, studie na zvíratech tento účinek nepotvrdily. Ve studii na myších byl zjištěn naopak účinek anxiogenní, tedy vyvolávající úzkost. Extrakt z muškátového oříšku inhiboval anxiolytický účinek různých léčiv, ondasetronu, buspironu a diazepamu. Tyto látky mají různý mechanismus účinku, anxiogenní působení muškátového oříšku je

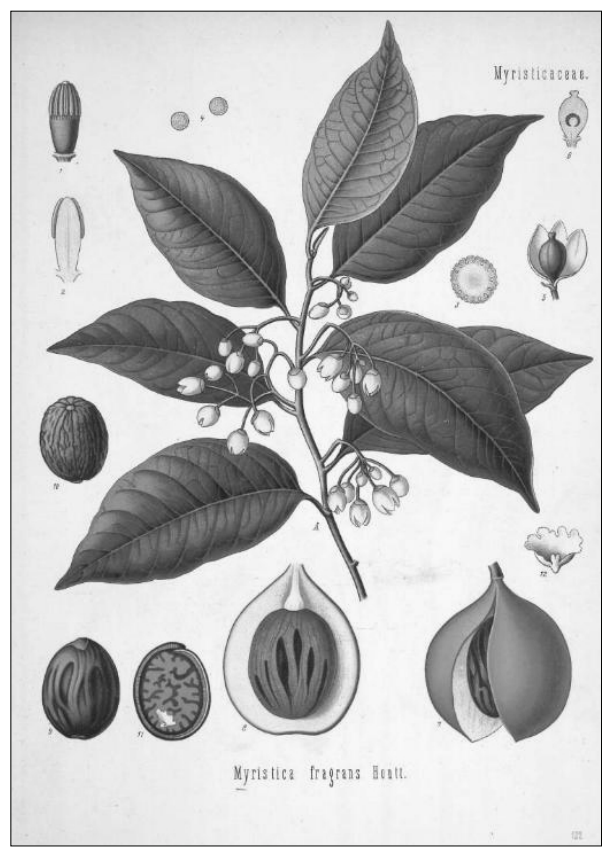

tedy nespecifické (Sonavane et al., 2002). $\mathrm{V}$ experimentu na potkanech myristicin snižoval anxiolytický účinek midazolamu (Leiter et al., 2011).

\section{Ocimum sanctum}

Ocimum sanctum L. (bazalka posvátná) je jednoletá bylina s větvenou lodyhou a drobnými světle růžovými květy, patři do čeledi Lamiaceae (hluchavkovité). Pochází z Indie, kde se také hojně pěstuje, nazývána je zde Tulsi. Z rostliny se používají listy, kořeny i semena (Khare, 2007).

Rostliny obsahují silici, hlavními složkami jsou eugenol, karvakrol, nerol a eugenolmethylether. Dále rostliny obsahují ursolovou kyselinu a flavonoidy (apigenin, luteolin, apigenin-7-Oglukuronid, luteolin-7-O-glukuronidorientin a molludistin) (Khare, 2007; Bhattacharyya et al., 2008).

Listy se v Indii po tisíce let hojně využívají $\mathrm{v}$ tradiční medicíně, a to jako karminativum, stomachikum, spasmolytikum, expektorans, antiastmatikum a antipyretikum. Použivají se také $\mathrm{k}$ léčbě revmatismu, nachlazení aj. Rostlina má také adaptogenní a protistresové účinky. Kořeny 
se používají k léčbě malárie, semena pak k léčbě psychických onemocnění, úzkosti a obsesí (Khare, 2007). V Asii se rovněž používá jako koření (Seidemann, 2005).

$\mathrm{V}$ různých studiích byl zjištěn účinek hypoglykemický, hypolipidemický, adaptogenní, antidepresivní, hepatoprotektivní, protirakovinný, analgetický a protizánětlivý (Bhattacharyya et al., 2008).

$\mathrm{V}$ experimentu na potkanech byl zvíratům podáván extrakt bazalky posvátné a čajovníku čínského (Camellia sinensis /L./ Kuntze), $\mathrm{v}$ různých testech byl zjištěn anxiolytický a antidepresivní účinek této kombinace (Tabassum et al., 2010). V experimentu na myších byl také zjištěn anxiolytický a antidepresivní účinek extraktu Ocimum sanctum (Chatterjee et al., 2011).

Zkoumán byl také účinek Ocimum sanctum u pacientů s generalizovanou úzkostnou poruchou (GAD - generalized anxiety disorder). Extrakt signifikantně snižuje symptomy úzkosti při GAD a je možné, že v budoucnosti nalezne své využití $\mathrm{v}$ léčbě úzkostných poruch (Bhattacharyya et al., 2008).

\section{Panax ginseng, $P$. quinquefolius}

Panax ginseng C. A. Mey. (všehoj ženšenový, ženšen pravý) a Panax quinquefolius L. (všehoj pětilistý, ženšen americký) jsou vytrvalé 30$60 \mathrm{~cm}$ vysoké byliny z čeledi Araliaceae (aralkovité). Rostliny mají dužnaté větvené kořeny, jednoduchou lodyhu a dlanitě složené listy. Květy jsou uspořádané v okolících, drobné, bílé, dozrávají ve výrazně červené peckovice. Panax ginseng roste $\mathrm{v}$ horských oblastech východní Asie, P. quinquefolius pochází ze Severní Ameriky. Panax ginseng se pěstuje v Č́ně, Rusku, Koreji a Japonsku, P. quinquefolius se pěstuje v USA a v Kanadě a vyváží se zejména do Číny (van Wyk, Wink, 2005; Zhengyi, Raven, 2007). K léčebným účelům se používají i další druhy rodu Panax, např. P. pseudoginseng Wall. a $P$. notoginseng (Burkill) F. H. Chen (Bruneton, 1999).

Druh Panax ginseng poskytuje drogu Ginseng radix, která je lékopisná dle Českého lékopisu 2009. Drogu tvoří sušený kořen, který se označuje jako bílý všehojový kořen, po úpravě parou a následném vysušení se označuje jako červený všehojový kořen (kolektiv autorů, 2009).

Ženšen se využívá v tradiční východní medicíně již po tisíce let, jeho působení na organismus lze popsat jako adaptogenní - tj. zvyšující fyzickou a psychickou odolnost organismu a odstraňující únavu (van Wyk, Wink, 2005). Latinské jméno Panax pochází z řeckých slov pan $=$ vše a akos = lék (Polívka, 1908). Popsána byla i řada dalších léčivých účinků - např. hypoglykemický, protizánětlivý, imunostimulační a protinádorový (Choi, 2008).

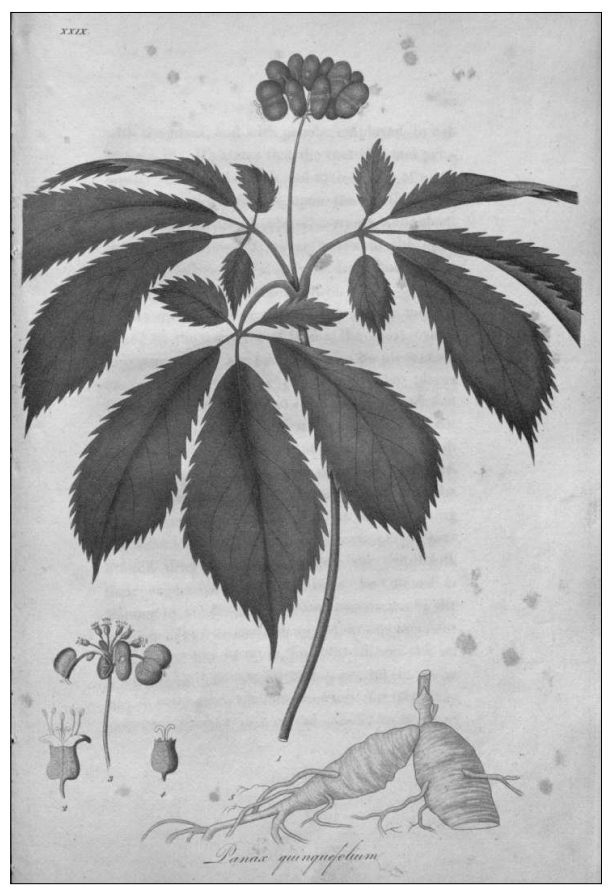

Rostliny obsahují komplex triterpenických saponinů, tzv. ginsenosidů, aglykonem jsou 20(S)-protopanaxadiol a 20(S)-protopanaxatriol. Nejdůležitější jsou ginsenosidy $\mathrm{Rg}_{1}, \mathrm{Rc}, \mathrm{Rd}, \mathrm{Rb}_{1}$, $\mathrm{Rb}_{2}$ a $\mathrm{Rb}_{0}$. Dále jsou prítomny polyacetyleny (ginsenoyny A-K) a menší množství silice (van Wyk, Wink, 2005).

V testech na zvíratech (Dang et al., 2009; Xu et al., 2010) bylo zjištěno silné antidepresivní působení ginsenosidů na organismus. Po aplikaci 20(S)-protopanaxadiolu dochází ke zvýšení hladiny noradrenalinu a serotoninu $\mathrm{v}$ mozku. Vzhledem k tomu, že inhibice re-uptake monoaminů je slabá, je možné, že tato látka působí v mozku ještě dalším mechanismem, odlišným od současných antidepresiv (Xu et al., 2010).

Významné je i anxiolytické působení ženšenu. $\mathrm{V}$ experimentu na myších byl zjištěn anxiolytický účinek ginsenosidů $\mathrm{Rb}_{1}, \mathrm{Rg}_{1}, \mathrm{Rg}_{5}$ a $\mathrm{R}_{\mathrm{k}}$ (Cha et al., 2005). 
$\mathrm{V}$ dalším experimentu na myších byl $\mathrm{v}$ různých testech zkoumán anxiolytický účinek extraktu Panax quinquefolium, jako standard byl zvolen diazepam. $V$ některých testech vykazoval extrakt ze ženšenu signifikantní anxiolytický účinek. Přestože v některých testech byl diazepam účinnější, při užívání ženšenu se projevovalo méně nežádoucích účinků. Mechanismus účinku dosud není zcela objasněn (Wei et al., 2007).

$\mathrm{V}$ experimentu na myších bylo zjištěno anxiolytické působení extraktu Panax ginseng obsahujícího $\operatorname{Rg}_{3}$ a $\mathrm{Rh}_{2}$ ginsenosidy. Tento účinek byl antagonizován působením flumazenilu, antagonisty benzodiazepinových receptorů (Kim et al., 2009).

Experiment na potkanech potvrdil antidepresivní a anxiolytický účinek, došlo $\mathrm{k}$ potlačení symptomů z odnětí morfinu. Ovlivněno bylo uvolňování kortikotropin-releasing faktoru (CRF) a neuropeptidu Y (NPY) v hypothalamu. Extrakt ze ženšenu snižoval uvolňování CRF a zvyšoval uvolňování NPY. Ovlivnění těchto systémů se jeví jako možná strategie při léčbě úzkostných poruch (Votava et al., 2005; Lee, 2011).

Standardizovaný extrakt ze ženšenu G115 je součástí rady vitaminových prŕpravků a potravních doplňků.

\section{Passiflora incarnata}

Passiflora incarnata L. (mučenka pletnî) je dřevnatá liána s lysými laločnatými listy, v úžlabí listů vyrůstají ovíjivé úponky, kterými se přichytává k okolním rostlinám. Patří do čeledi Passifloraceae (mučenkovité). Nápadné jsou velké bílofialové květy s charakteristickým vzhledem, latinské jméno Passiflora i české mučenka pochází z toho, že jednotlivé květní části mají připomínat nástroje, kterými byl mučen Ježíš Kristus (passio $=$ utrpení, flos = květ). Podle jezuity J. Ferrariho, žijícího v 16. století, mají čnělky připomínat hřeby, kterými byl Kristus prribit ke křiži, tyčinky 5 ran, stopkatý semeník kalich utrpení, třásnitá pakorunka trnovou korunu a spirálovitě stočené úponky pak důtky, kterými byl Kristus mrskán (Polívka, 1908). Mučenka pletní pochází z východní a jižní části Severní Ameriky. K léčebným účelům se používá nat' (Passiflorae herba), droga je lékopisná dle Českého lékopisu 2009 (van Wyk, Wink, 2005; kolektiv autorů, 2009). Různé léčivé účinky vykazují i některé další druhy mučenek, např. Passiflora quadrangularis L., $P$. edulis Sims a $P$. foetida $\mathrm{L}$. (Dhawan et al., 2004).

Rostliny obsahují flavonoidy (vitexin, isovitexin, apigenin, luteolin, schaftosid, isoschaftosid, swertisin), deriváty $\gamma$-pyrolu (maltol a ethylmaltol), polyacetyleny (passicol) a kyanogenní glykosidy (gynokardin). Rozlišují se 2 chemotypy, které se liší zastoupením jednotlivých látek. Jeden chemotyp obsahuje jako hlavní složku isovitexin, schaftosid a isoschaftosid, druhý chemotyp obsahuje zejména swertisin a menší množství schaftosidu a isoschaftosidu. Dále mučenka obsahuje indolové alkaloidy harminového typu: harman, harmin, harmalin, harmol a harmalol (Soulimani et al., 1997; Wohlmuth et al., 2010).

Mučenka se tradičně používá jako sedativum, anxiolytikum a spasmolytikum, zevně pak k léčbě vředů a hemoroidů (Dhawan et al., 2001).

$\mathrm{V}$ experimentu na myších vykazoval extrakt z mučenky signifikantní anxiolytický účinek. Došlo také ke zvýšení účinku pentobarbitalu (Soulimani et al., 1997). V dalších studiích na zvíratech byl potvrzen anxiolytický účinek (Dhawan et al., 2001a, b).

Ve studii na myších byl anxiolytický účinek srovnatelný s diazepamem, antagonizován byl flumazenilem (Grundmann et al., 2008).

V pilotní dvojitě slepé studii byl srovnáván účinek Passiflora incarnata a oxazepamu v léčbě generalizované úzkostné poruchy. Po 4 dnech léčby byl účinek obou léčiv srovnatelný, príčemž při užívání mučenky se vyskytlo méně nežádoucích účinků. Protože studie byla prováděna pouze na 36 pacientech, jsou potřeba další podrobnější studie (Akhonzadekh et al., 2001).

$\mathrm{V}$ dvojitě slepé, placebem kontrolované studii na 60 pacientech byl zkoumán účinek Passiflora incarnata při léčbě předoperační úzkosti. Extrakt byl oproti placebu signifikantně účinnější v odstraňování úzkostných přiznaků (Movafegh et al., 2008).

$\mathrm{V}$ dvojitě slepé, placebem kontrolované studii zlepšoval čaj z mučenky kvalitu spánku (Ngan, Conduit, 2011).

Mučenka je na trhu k dispozici ve formě tinktury určené $\mathrm{k}$ léčbě úzkosti a nespavosti, prodává se také sušená drcená nat'.

\section{Piper methysticum}

Piper methysticum Forster f. (peprovník opojný) je dvoudomý keř z čeledi Piperaceae 
(pepřovníkovité), známý je především pod tradičním jménem kava-kava. Rostliny mají silný kořen, vysoké jsou 2-5 m. Listy jsou vejčité až srdčité. Pochází ze západního Tichomoří (Melanésie, Polynésie, Mikronésie), kde je využíván domorodci pro své opojné a euforizující účinky. Z rozžvýkaných zkvašených kořenů mladých rostlin se připravuje nápoj, jehož požívání bylo spojeno s náboženskými obřady (Patočka, Strunecká, 2001).

Název drogy je odvozen z polynéského slova awa, výraz awa-awa má význam velmi hořký, nebot' jak droga, tak nápoj z ní připravený mají výrazně hořkou chut'. Pod názvem awa-awa je droga známa na Havajských ostrovech a na Samoi, název kava či kava-kava (pod kterým známe rostlinu v Evropě) se používá na ostrovech Tonga a na Markézách. Na ostrovech Fidži jsou droga a nápoj z ní připravený nazývány yangona či yagona. Nápoj vyvolává zlepšení nálady, snižuje vnímání bolesti a umožňuje lépe snášet fyzickou zátěž. Ve vyšších dávkách má nápoj především účinek uklidňující až narkotický (Patočka, Strunecká, 2001; Singh, 2004).

Kava-kava obsahuje směs laktonů, tzv. kavapyronů (kavain, dihydrokavain, methysticin, dihydromethisticin, yangonin, desmethoxyyangonin). Kavapyronů je v sušené droze 9-12\%, z hlediska farmakologických účinků drogy jsou nejdůležitější. Dále rostlina obsahuje lipidy, sacharidy, minerály a proteiny. Nejvyšší obsah kavapyronů má kořen a oddenek, méně pak nadzemní části, různé části rostlin pak mají jednotlivé látky zastoupené $v$ různém poměru. Různé chemotypy peprovnníku se také liší obsahem účinných látek (Patočka, Strunecká, 2001; Singh, 2004). V nadzemních částech rostliny jsou obsaženy také piperidinové alkaloidy pipermethystin, $3 \alpha, 4 \alpha$-epoxy- $5 \beta$-pipermethystin a awain (Dragull et al., 2003).

Většina farmakologických účinků pepřovníku opojného je zprostředkována 6 kavalaktony: methysticinem, dihydromethysticinem, kavainem, dihydrokavainem, demethoxyyangoninem a yangoninem. $\mathrm{V}$ různých studiích byly zjištěny účinky anxiolytické, sedativní, hypnotické, antikonvulzivní, analgetické, myorelaxační, antitrombotické a neuroprotektivní (Sarris et al., 2011).

$\mathrm{Na}$ základě in vitro i in vivo studií na zvíratech i na lidech se předpokládají různé mechanismy působení pepróovníku na nervový systém. Jde o blokádu napět'ově řízených sodíkových kaná- lů, snížení vylučování excitačních neurotransmiterů prostřednictvím blokády vápníkových kanálů, ovlivnění GABA-A receptorů, reverzibilní inhibici monoaminoxidázy $\mathrm{B}$ a inhibici re-uptake noradrenalinu a dopaminu. Na rozdíl od benzodiazepinů se kavalaktony neváží prímo na GABA receptory (Sarris et al., 2011).

$\mathrm{Na}$ základě metaanalýzy byla kava $\mathrm{v}$ různých studiích signifikantně účinnější proti placebu $\mathrm{v}$ léčbě úzkostných poruch. $\mathrm{V}$ jiných studiích byl úćinek srovnáván s buspironem a opipramolem, a to při léčbě generalizované úzkostné poruchy, kde tato léčiva byla srovnatelně účinná. $\mathrm{Na}$ rozdíl od benzodiazepinů má kava minimální vliv na kognitivní funkce, riziko závislosti a rebound fenoménu (Sarris, Kavanagh, 2009).

Standardizovaný extrakt je používán jako anxiolytikum $\mathrm{k}$ léčbě úzkosti a psychosomatických potíží. V České republice byly registrovány přípravky Leikan a Kavasedon, které se používaly $\mathrm{k}$ léčbě úzkosti a nespavosti. Později se objevily zprávy o jejich hepatotoxicitě a v roce 2002 byly staženy z prodeje.

\section{Sceletium tortuosum}

Sceletium tortuosum (L.) N. E. Br. je vytrvalá sukulentní rostlina z čeledi Aizoaceae (kosmatcovité), některými autory je řazena do rodu Mesembryanthemum či Phyllobolus. Rostliny mají krátké lodyhy a dužnaté listy, na vrcholech lodyh kvetou světle žlutými až žlutooranžovými květy. Latinský název rostliny pochází z řeckého slova skeletos $=$ kostra (lat. sceletum), a to podle suchých listů se zachovanou „skeletonizovanou“ žilnatinou, které na rostlině zůstávají a v době sucha chrání její mladé části. Sceletium tortuosum pochází ze suchých oblastí Jižní Afriky (z jihozápadní části Kapska a Namaqualandu), typy s vysokým obsahem alkaloidů se v Jižní Africe komerčně pěstují (van Wyk, Wink, 2005; Hartmann, 2001).

Používání rostliny africkými domorodci bylo Evropany zaznamenáno již v 17. století, využívána je však pravděpodobně tisíce let. Původní afričtí obyvatelé Khoi-San (Khoi-Khoi a Sanové) použivali rostlinu pod jménem kanna či kougoed k odstranění pocitu hladu a žízně, k léčbě koliky a na zlepšení nálady. Původním způsobem aplikace bylo žvýkání fermentovaných a usušených lodyh. Možné je i využití ve formě tinktury či nálevu nebo kouřením či šnupáním (Gericke, Viljoen, 2008). 
Sceletium tortuosum obsahuje alkaloidy mesembrinového typu, které se dělí podle struktury na tři hlavní skupiny (mesembrin, mesembrenon, mesembrenol, mesembranol, tortuosamin, joubertiamin a dalšîi). Hlavním alkaloidem je mesembrin a mesembrenon, zastoupení jednotlivých alkaloidů se však může výrazně lišit (Smith et al., 1996). Poměr jednotlivých alkaloidů v rostlině se mění také během tradiční přípravy fermentací (Smith et al., 1998; Patnala, Kanfer, 2009). Obsah alkaloidů v rostlině silně kolísá - suchý materiál obsahuje od 0,05 do 2,3\% alkaloidů, je ovlivněn řadou vnějších i vnitřních faktorů (Gericke, Viljoen, 2008).

Mesembrin působí jako silný inhibitor zpětného vychytávání serotoninu ze synaptické štěrbiny, další látky pravděpodobně působí na různých typech receptorů. Ve velkých dávkách inhibuje v malé míre i zpětné vychytávání noradrenalinu a dopaminu (Gericke, Viljoen, 2008). Uvádí se, že mesembrin je silnější inhibitor re-uptake serotoninu než imipramin (Gericke, van Wyk, 2001). Inhibice zpětného vychytávání serotoninu je pravděpodobně hlavním mechanismem, který vysvětluje farmakologické a klinické účinky Sceletium tortuosum na organismus. Dalším mechanismem působení je pravděpodobně inhibice fosfodiesterázy-4 (PDE4) (Napoletano et al., 2001). Schopnost inhibice re-uptake serotoninu a inhibice PDE4 byla potvrzena i u mesembrenonu (Harvey et al., 2010).

Ve Spojených státech byl podán patent na použití mesembrinu a prúbuzných látek jako inhibitorů re-uptake serotoninu k léčbě deprese, úzkosti, bulimie a obsedantně-kompulzivní poruchy (Gericke, van Wyk, 2001). Jihoafrická společnost HGH Pharmaceuticals vyvíjí přípravek Zembrin, který obsahuje standardizovaný extrakt Sceletium tortuosum (www.zembrin.com).

\section{Withania somnifera}

Withania somnifera (L.) Dunal syn. Physalis somnifera L. (vithánie snodárná, ashwagandha) je vytrvalá bylina z čeledi Solanaceae (lilkovité). Známá je také pod jménem indický ženšen. Rozvětvená lodyha může být vysoká až 2,5 m a vzhledem tak připomíná malý keřík. Rostliny mají oválné strrídavé listy, květy jsou drobné, nahloučené na začátku vedlejších větví. Plodem jsou červené bobule obalené nafouklým vytrvávajícím kalichem, podobně jako plody mochyně (Physalis alkekengi). Kořeny jsou hladké, 1-2 cm široké a 30-40 cm dlouhé. Rostlina pochází ze severní Afriky, hojně je rozšířena v Iráku, Pákistánu, severní Indii a v Číně. V těchto oblastech se často využívá v tradiční medicíně (Rätsch, 2005; van Wyk, Wink, 2005).

Rostliny obsahují více než 80 biologicky aktivních látek: alkaloidy (isopelletierin, anaferin, anahygrin, withasomnin, cuscohygrin, ashwagandhin, ashwagandhinin), steroidní laktony (withanolidy A-Y, withaferiny, withasomniferiny A-C a dalšî), fytosteroly a saponiny. Je známa rada chemotypů Withania somnifera (Williamson, 2003; Wink, van Wyk, 2008).

Obsahové látky Withania somnifera mají řadu zajímavých účinků na organismus. Zjištěny byly účinky antioxidační, adaptogenní, sedativní, hypnotické, protizánětlivé, protinádorové a imunomodulační, příznivý vliv mají také na kardiovaskulární a krvetvorný systém (Mishra et al., 2000). Withania pomáhá také při neurodegenerativních onemocněních, obsahové látky mají nootropní účinek a inhibují acetycholinesterázu (Dhuley, 2001; Choudhary et al., 2004).

$\mathrm{V}$ experimentu na potkanech byl srovnáván anxiolytický účinek glykowithanolidů s lorazepamem a antidepresivní s imipraminem. Anxiolytický účinek glykowithanolidů byl srovnatelný s lorazepamem, obě látky působily proti anxiogennímu účinku pentylenetetrazolu. Antidepresivní účinek byl srovnatelný s imipraminem (Bhattacharya et al., 2000).

$\mathrm{V}$ experimentu na potkanech zvyšoval extrakt $z$ vithánie odolnost vůči stresu (Bhattacharya, Muruganandam, 2003).

V dvojitě slepé, placebem kontrolované studii byl pacientům s úzkostnými poruchami podáván extrakt Withania somnifera. Po 6 týdnech byl extrakt z vithánie signifikantně účinnější než placebo, přitom nevykazoval více nežádoucích účinků než placebo. Vithánie se tedy jeví jako šetrné anxiolytikum a v tomto ohledu jsou potřeba další studie (Andrade et al., 2000).

V České republice jsou na trhu potravní doplňky a čajové směsi s obsahem vithánie, prodává se také drcený sušený kořen.

\section{Zingiber officinale}

Zingiber officinale Roscoe (zázvor lékařský) je vytrvalá bylina z čeledi Zingiberaceae (zázvorovité). Rostliny jsou cca $1 \mathrm{~m}$ vysoké, listy vyrůstají z tlustého větveného oddenku. Květy jsou 
žluto-červené, vyrůstají $\mathrm{v}$ hustých klasech na prodloužených stoncích.

Zázvor pochází pravděpodobně ze severovýchodní Indie, je to ale stará kulturní rostlina, která nebyla nalezena v přírodě. Rozmnožuje se vegetativně pomocí oddenků. Pěstuje se v tropických a subtropických oblastech celého světa (van Wyk, Wink, 2005).

Rostlina poskytuje drogu Zingiberis rhizoma, která je lékopisná dle Českého lékopisu 2009. Drogu tvoří sušený oddenek charakteristické vůně a pálivé kořenité chuti (kolektiv autorů, 2009).

Zázvor obsahuje 0,25-3,3 \% silice složené $\mathrm{z}$ monoterpenů (geranial, neral) a seskviterpenů ( $\beta$-seskviphellandren, $\beta$-bisabolen, kurkumen, zingiberen), dále pálivé látky gingeroly a shogaoly, fenolické látky, diarylheptenony, diterpeny, gingesulfonovou kyselinu a monoacyldigalaktosylglykosidy (ESCOP, 2003).

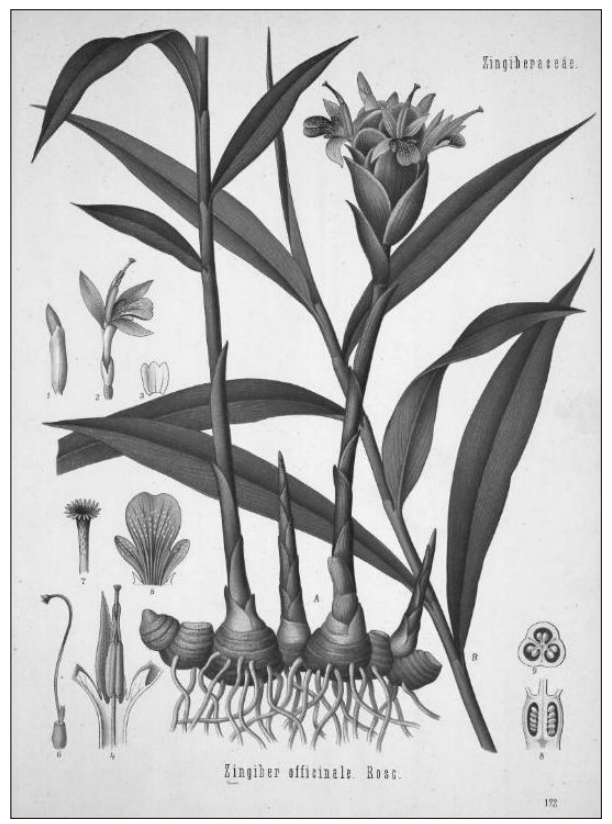

Zázvor se používá zejména jako antiemetikum, a to u těhotných žen, při kinetóze a pooperačních stavech. Dále se používá při artritidě a vaskulárních onemocněních (White, 2007). Má i další účinky: antioxidační, antibakteriální, radioprotektivní, protizánětlivý, analgetický, antitrombotický, vazodilatační, hypotenzivní, antikonvulzivní a antiulcerózní (Ali et al., 2008).

Kromě těchto účinků má zázvor i účinek antidepresivní a anxiolytický.
Ve studii na potkanech byl srovnáván anxiolytický účinek diazepamu a kombinovaného extraktu zázvoru a jinanu dvoulaločného. $V$ některých testech byl účinek diazepamu a extraktu srovnatelný, ale vysoké dávky extraktu mohou působit naopak anxiogenně. Anxiolytický účinek pravděpodobně souvisí s ovlivněním serotonergního systému (Hasenöhrl et al., 1996). Na rozdíl od diazepamu nemá tato kombinace negativní vliv na kognitivní funkce (Hasenöhrl et al., 1998).

$\mathrm{V}$ experimentu na myších byl podáván extrakt z kůry magnolie a z oddenku zázvoru. Zázvor a magnolie zde působí synergicky, ovlivněním serotonergního a noradrenergního systému dochází k antidepresivnímu účinku (Qiang et al., 2009; Yi et al., 2009).

$\mathrm{V}$ experimentu na potkanech byl zjištěn anxiolytický účinek extraktu ze zázvoru, který zesiloval účinek diazepamu a rušil emetogenní účinek síranu lithného. Dochází zde k ovlivnění dopaminergní a serotonergní transmise $\mathrm{v}$ mozku (Vishwakarma et al., 2002).

Přestože se zázvor použivá především jako antiemetikum, je možné ho použít i jako šetrné anxiolytikum a antidepresivum.

\section{Ziziphus jujuba}

Ziziphus jujuba Mill. (cicimek jojoba, jojoba trnitá) je trnitý opadavý keř nebo malý strom z čeledi Rhamnaceae (řešetlákovité). Rostliny mají lesklé tuhé střídavé listy a nenápadné žlutozelené květy, které dozrávají v červené až červenohnědé 2-5 cm dlouhé peckovice. Rostlina pochází z Číny, rozšířena je v subtropických oblastech jihovýchodní Evropy, Přední a Střední Asie, jihovýchodní a východní Asie. Široce se pěstuje zejména $\mathrm{v}$ teplejších oblastech Evropy a v Ćíně. Rostlina poskytuje drogu Ziziphi fructus, kterou tvoří sušené plody, někdy nazývané též čínské datle. Plody jsou jedlé a konzumují se čerstvé i sušené. K léčebným účelům se použivají také semena (Valíček, 2002; van Wyk, Wink, 2005).

Semena jojoby obsahují řadu biologicky aktivních látek: cyklopeptidické alkaloidy, triterpenoidy, triterpenoidní saponiny dammaranového typu, flavonoidy a steroidní látky. Z alkaloidů je zastoupen zejména sanjoinin A, který je totožný $s$ dřive popsaným alkaloidem frangufolinem, dále pak jubanin-C, scutianin-C a ziziphin-A (Tripathi et al., 2001; Li et al., 2005; van Wyk, Wink, 2005). 
Plody a semena jojoby se tradičně používajî k léčbě nachlazení, astmatu, diabetu, kožních problémů, úzkosti a nespavosti a jako tonikum. Plody jsou jedlé (van Wyk, Wink, 2005; WHO, 2007). Moderní farmakologické studie potvrdily řadu účinků jojoby na organismus: hypnotický, sedativní, antikonvulzivní, analgetický, protizánětlivý, hypotenzivní, hypolipidemický a hypotermický (Peng et al., 2000; WHO, 2007).

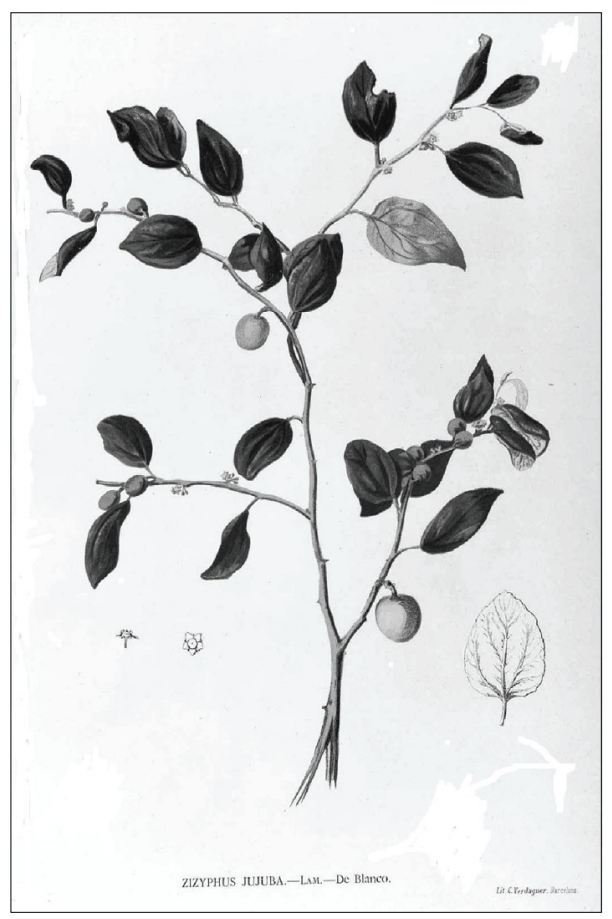

V experimentu na myších vykazoval extrakt ze semen jojoby anxiolytický účinek, ve vyšších dávkách pak účinek hypnotický. Extrakt také prodlužoval účinek hexobarbitalu. Dochází zde $\mathrm{k}$ ovlivnění monoaminergní transmise $\mathrm{v}$ mozku (Peng et al., 2000). V dalším experimentu na myších byl srovnáván anxiolytický účinek sanjoininu A a diazepamu. Sanjoinin vykazoval anxiolytický účinek, který byl zprostředkován ovlivněním GABAergního systému $\mathrm{v}$ mozku otevíráním chloridových kanálů aktivací GABA-benzodiazepinových receptorů. $\mathrm{V}$ některých testech měl sanjoinin silnější anxiolytický účinek než diazepam a na rozdíl od diazepamu neměl sanjoinin myorelaxační účinek a v nižších dávkách ani účinek hypnotický. Sanjoinin A se tedy jeví jako slibná sloučenina s anxiolytickým účinkem (Han et al., 2009).

\section{ZÁVĚR}

Úzkostné a depresivní poruchy jsou v současné době velmi časté, proto je výzkum a vývoj léčiv určených $\mathrm{k}$ léčbě těchto onemocnění perspektivní. Existuje mnoho rostlin, které se $\mathrm{v}$ různých kulturách po celém světě tradičně používají k léčbě psychických onemocnění. Některé se používají v lidové medicíně ve formě čajů a extraktů, jiné jsou již $\mathrm{k}$ dispozici ve formě potravních doplňků i registrovaných léčivých přípravků. Další výzkum účinků obsahových látek rostlin a mechanismu jejich působení na organismus může vést $\mathrm{k}$ novým léčivům. Intenzivní výzkum proto probíhá.

Rostliny i další živé organismy v sobě skrývají obrovský potenciál pro budoucnost, a proto je třeba je zachovat i pro další generace. Jednou vyhynulý a dosud neprozkoumaný druh je včetně obsahových látek navždy ztracený a jedním $z$ důvodů pro ochranu biodiverzity by tedy mělo být i jejich případné medicínské využití $\mathrm{v}$ budoucnosti. Velký problém také představuje zavádění „civilizace“ a konvenční medicíny do tradičních kultur, zejména $\mathrm{v}$ tropických oblastech. S vymírajícími kulturami pak nenávratně mizí $\mathrm{i}$ informace o medicínském využití řady rostlin, získávané po tisíce let. Důležitý je proto také etnobotanický a etnofarmakologický výzkum $\mathrm{v}$ dosud neprozkoumaných oblastech (Plotkin, 1994, 2001).

\section{LITERATURA}

1. Akhondzadeh S, Naghavi HR, Vazirian M, Shayeganpour A, Rashidi H, Khani M (2001). Passionflower in the treatment of generalized anxiety: a pilot double-blind randomized controlled trial with oxazepam. J Clin Pharm Ther. 26/5: 363-367.

2. Ali BH, Blunden G, Tanira MO, Nemmar A. Ali BH, Blunden G, Tanira MO, Nemmar A (2008). Some phytochemical, pharmacological and toxicological properties of ginger (Zingiber officinale Roscoe): a review of recent research. Food Chem Toxicol. 46/2: 409-420.

3. Andrade C, Aswath A, Chaturvedi SK, Srinivasa M, Raguram R (2000). A double-blind, placebocontrolled evaluation of the anxiolytic efficacy of an ethanolic extract of Withania somnifera. Indian J Psychiatry. 42/3: 295-301.

4. Anonym (2004). Bacopa monniera Monograph. Altern Med Rev. 9/1: 79-85.

5. Bhattacharyya D, Sur TK, Jana U, Debnath PK (2008). Controlled programmed trial of Ocimum sanctum leaf on generalized anxiety disorders. Nepal Med Coll J. 10/3: 176-179. 
6. Bhattacharya SK, Ghoshal S (1998). Anxiolytic activity of a standardized extract of Bacopa monniera: an experimental study. Phytomedicine. 5/2: 77-82.

7. Bhattacharya SK, Muruganandam AV (2003). Adaptogenic activity of Withania somnifera: an experimental study using a rat model of chronic stress. Pharmacol Biochem Behav. 75/3: 547-555.

8. Bhattacharya SK, Bhattacharya A, Sairam K, Ghosal S (2000). Anxiolytic-antidepressant activity of Withania somnifera glycowithanolides: an experimental study. Phytomedicine. 7/6: 463-469.

9. Brinkhaus B, Lindner M, Schuppan D, Hahn EG (2000). Chemical, pharmacological and clinical profile of the East Asian medical plant Centella asiatica. Phytomedicine. 7/5: 427-448.

10. Bruneton J (1999). Pharmacognosy. Phytochemistry. Medicinal Plants. $2^{\text {nd }}$ ed. Intercept Ltd, Londres, Paris, New York. 1119 p.

11. Calabrese C, Gregory WL, Leo M, Kaemer D, Bone K, Oken B (2008). Effects of a Standardized Bacopa monnieri Extract on Cognitive Performance, Anxiety, and Depression in the Elderly: A Randomized, Double-Blind, Placebo-Controlled Trial. J Altern Complement Med. 14/6: 707-713.

12. Carvalho AC, Almeida DS, Melo MG, Cavalcanti SC, Marçal RM (2009). Evidence of the mechanism of action of Erythrina velutina Willd (Fabaceae) leaves aqueous extract. J Ethnopharmacol. 122/2: 374-378.

13. Carvalho-Freitas MIR, Costa M (2002). Anxiolytic and Sedative Effects of Extracts and Essential Oil from Citrus aurantium L. Biol Pharm Bull. 25/12: 1629-1633.

14. Dang H, Chen Y, Liu X, Wang Q, Wang L, Jia W, Wang Y (2009). Antidepressant effects of ginseng total saponins in the forced swimming test and chronic mild stress models of depression. Prog Neuropsychopharmacol Biol Psych. 33/8: 1417-1424.

15. Demetriades AK, Wallman PD, McGuiness A, Gavalas MC (2005). Low cost, high risk: accidental nutmeg intoxication. Emerg Med J. 22/3: 223-225.

16. Deng S, West BJ (2011). Antidepressant Effects of Noni Fruit and its Active Principals. Asian J Med Sci. 3/2: 79-83.

17. Deng S, West BJ, Palu AK, Zhou B-N, Jensen CJ (2007). Noni as an anxiolytic and sedative: A mechanism involving its gamma-aminobutyric acidergic effects. Phytomedicine. 14/7-8: 517-522.

18. Dhawan K, Kumar S, Sharma A (2001a). Antianxiety studies on extracts of Passiflora incarnata Linneaus. J Ethnopharmacol. 78/2-3: 165-170.

19. Dhawan K, Kumar S, Sharma A (2001b). Anxiolytic activity of aerial and underground parts of Passiflora incarnata. Fitoterapia. 72/8: 922-926.

20. Dhawan K, Dhawan S, Sharma A (2004). Passiflora: a review update. J Ethnopharmacol. 94/1: 1-23.

21. Dhuley JN (2001). Nootropic-like Effect of Ashwagandha (Withania somnifera L.) in Mice. Phytother. Res. 15/6: 524-528.

22. Dong H, He L, Huang M, Dong Y (2008). Antiinflammatory components isolated from Atractylodes macrocephala Koidz. Nat Prod Res. 22/16: 14181427.
23. Dragull K, Yoshida WY, Tang CS (2003). Piperidine alkaloids from Piper methysticum. Phytochemistry. 63/2: 193-198.

24. Duke JA (2009). Duke's Handbook of Medicinal Plants of Latin America. CRC Press. 901 p.

25. ESCOP (European Scientific Cooperative on Phytotherapy) (2003). The ESCOP Monographs $2^{\text {nd }}$ ed. $556 \mathrm{p}$.

26. Faturi CB, Leite JR, Alves PB, Canton AC, TeixeiraSilva F (2010). Anxiolytic-like effect of sweet orange aroma in Wistar rats. Prog Neuropsychopharmacol Biol Psych. 34/4: 605-609.

27. Flausino OA, Jr., Pereira AM, da Silva Bolzani V, Nunes-de-Souza RL (2007). Effects of erythrinian alkaloids isolated from Erythrina mulungu (Papilionaceae) in mice submitted to animal models of anxiety. Biol Pharm Bull. 30/2: 375-378.

28. Gericke N, van Wyk B-E (2001). Pharmaceutical compositions containing mesembrine and related compounds. United States Patent US 6,288,104 B1.

29. Gericke N, Viljoen AM (2008). Sceletium - A review update. J Ethnopharmacol. 119/3: 653-663.

30. Ghassemi N, Sajjadi SE, Ghannadi A, ShamsArdakani M, Mehrabani M (2003). Volatile constituents of Echium amoenum. DARU. 11/1: 32-33.

31. Gholamzadeh S, Zare S, Ilkhanipoor M (2007). Evaluation of the anxiolytic effect of Echium amoenum petals extract, during chronic treatment in rat. RPS. 2/2: 91-95.

32. Gohil KJ, Patel JA (2010). A review on Bacopa monniera: Current research and future prospects. Int J Green Pharm. 4/1: 1-9.

33. Gohil KJ, Patel JA, Gajjar AK (2010). Pharmacological Review on Centella asiatica: A Potential Herbal Cure-all. Indian J Pharm Sci. 72/5: 546-556.

34. Grundmann O, Wang J, McGregor GP, Butterweck V (2008). Anxiolytic activity of a phytochemically characterized Passiflora incarnata extract is mediated via the GABAergic system. Planta Med. 74/15: 1769-1773.

35. Hallström H, Thuvander A (1997). Toxicological evaluation of myristicin. Nat Toxins. 5/5: 186-192.

36. Han H, Ma Y, Eun JS, Li R, Hong JT, Lee MK, Oh KW (2009). Anxiolytic-like effects of sanjoinine A isolated from Zizyphi Spinosi Semen: possible involvement of GABAergic transmission. Pharmacol Biochem Behav. 92/2: 206-213.

37. Hartmann HEK (ed.) (2001). Illustrated handbook of succulent plants: Aizoaceae F-Z. Springer Berlin, Heidelberg, New York, Barcelona, Hong Kong, London, Milan, Paris, Tokyo, p. 287-290.

38. Harvey A, Gericke N, Viljoen A (2010). Use of pharmaceutical compositions containing mesembrenone. World Intellectual Property Organisation patent WO 2010/106494 A1.

39. Hasenöhrl RU, Nichau CH, Frisch $\mathrm{CH}$, De Souza Silva MA, Huston JP, Mattern CM, Häcker R (1996). Anxiolytic-like effect of combined extracts of Zingiber officinale and Ginkgo biloba in the elevated plus-maze. Pharmacol Biochem Behav. 53/2 271-275.

40. Hasenöhrl RU, Topic B, Frisch C, Häcker R, Mattern CM, Huston JP (1998). Dissociation between anxiolytic and hypomnestic effects for combined extracts 
of Zingiber officinale and Ginkgo biloba, as opposed to diazepam. Pharmacol Biochem Behav. 59/2: $527-$ 535.

41. Cha HY, Park JH, Hong JT, Yoo HS, Song S, Hwang BY, Eun JS, Oh KW (2005). Anxiolytic-like effects of ginsenosides on the elevated plus-maze model in mice. Biol Pharm Bull. 28/9: 1621-1625.

42. Chan-Blanco Y, Vaillant F, Perez AM, Reynes M, Brillouet JM, Brat P (2006). The noni fruit (Morinda citrifolia L.): A review of agricultural research, nutritional and therapeutic properties. J Food Compos Anal. 19/6-7: 645-654.

43. Charles PD, Ambigapathy G, Geraldine P, Akbarsha MA, Rajan KE (2011). Bacopa monniera leaf extract up-regulates tryptophan hydroxylase (TPH2) and serotonin transporter (SERT) expression: Implications in memory formation. J Ethnopharmacol. 134/1: $55-61$.

44. Chatterjee M, Verma P, Maurya R, Palit G (2011). Evaluation of ethanol leaf extract of Ocimum sanctum in experimental models of anxiety and depression. Pharm Biol. 49/5: 477-483.

45. Choi KT (2008). Botanical characteristics, pharmacological effects and medicinal components of Korean Panax ginseng C A Meyer. Acta Pharmacol Sin. 29/9: 1109-1118.

46. Choudhary MI, Yousuf S, Nawaz SA, Ahmed S, Atta-ur-Rahman (2004). Cholinesterase inhibiting withanolides from Withania somnifera. Chem Pharm Bull (Tokyo). 52/11: 1358-1361.

47. Jahodár L (2006). Farmakobotanika. Semenné rostliny. Praha: Karolinum. $258 \mathrm{~s}$.

48. Jain NN, Ohal CC, Shroff SK, Bhutada RH, Somani RS, Kasture VS, Kasture SB (2003). Clitoria ternatea and the CNS. Pharmacol Biochem Behav. 75/3: 529-536.

49. James JT, Dubery IA (2009). Pentacyclic triterpenoids from the medicinal herb, Centella asiatica (L.) Urban. Molecules. 14/10: 3922-3941.

50. Jana U, Sur TK, Maity LN, Debnath PK, Bhattacharyya D (2010). A clinical study on the management of generalized anxiety disorder with Centella asiatica. Nepal Med Coll J. 12/1: 8-11.

51. Jiang H, Shi J, Li Y (2011). Screening for Compounds with Aromatase Inhibiting Activities from Atractylodes macrocephala Koidz. Molecules. 16/4: 3146-3151.

52. Jyoti A, Sethi P, Sharma D (2007). Bacopa monniera prevents from aluminium neurotoxicity in the cerebral cortex of rat brain. J Ethnopharmacol. 111/1: $56-62$.

53. Kalandakanond S, Pandaranandaga J, Komolvanich S, Poonyachoti S (2004). A study on the anxiolytic effect of juice from the fruit of Noni (Morinda citrifolia L. Rubiaceae) on wistar rats. Thai J Vet Med. 34/1: 99-105.

54. Khare CP (2007). Indian Medicinal Herbs. An Illustrated Dictionary. Springer Berlin, Heidelberg. $812 \mathrm{p}$.

55. Kim TW, Choi HJ, Kim NJ, Kim DH (2009). Anxiolytic-like effects of ginsenosides $\mathrm{Rg}_{3}$ and $\mathrm{Rh}_{2}$ from red ginseng in the elevated plus-maze model. Planta Med. 75/8: 836-839.
56. Kolektiv autorů (2009). Český lékopis 2009. Praha: Grada. $1552 \mathrm{~s}$

57. Krol CG, Janssen MG (2010). Unusual use of nutmeg. Ned Tijdschr Geneeskd. 154: A2214. (article in Dutch)

58. Lee B, Kim H, Shim I, Lee H, Hahm DH (2011). Wild ginseng attenuates anxiety- and depression-like behaviors during morphine withdrawal. J Microbiol Biotechnol. 21/10: 1088-1096.

59. Lehrner J, Eckersberger C, Walla P, Pötsch G, Deecke L (2000). Ambient odor of orange in a dental office reduces anxiety and improves mood in female patients. Physiol Behav. 71/1-2: 83-86.

60. Leiter E, Hitchcock G, Godwin S, Johnson M, Sedgwick W, Jones W, McCall S, Ceremuga TE (2011). Evaluation of the anxiolytic properties of myristicin, a component of nutmeg, in the male Sprague-Dawley rat. AANA J. 79/2: 109-114.

61. Li CQ, He LCh, Dong HY, Jin JQ (2007). Screening for the anti-inflammatory activity of fractions and compounds from Atractylodes macrocephala Koidz. J Ethnopharmacol. 114/2: 212-217.

62. Li LM, Liao X, Peng SL, Ding LS (2005). Chemical constituents from the seeds of Ziziphus jujuba var. spinosa (Bunge) Hu. J Integrative Plant Biol. 47/4: 494-498.

63. Limpeanchob N, Jaipan S, Rattanakaruna S, Phrompittayaratb W (2008). Neuroprotective effect of Bacopa monnieri on beta-amyloid-induced cell death in primary cortical culture. J Ethnopharmacol. 120/1: 112-117.

64. Lin Y, Jin T, Wu X, Huang Z, Fan J (1997). A Novel Bisesquiterpenoid, Biatractylolide, from the Chinese Herbal Plant Atractylodes macrocephala. J Nat Prod. 60/1: 27-28.

65. Lopes Campêlo LM, Gonçalves e Sá C, de Almeida AA, da Costa JP, Marques TH, Feitosa CM, Saldanha GB, de Freitas RM (2011). Sedative, anxiolytic and antidepressant activities of Citrus limon (Burn) essential oil in mice. Pharmazie. 66/8: 623-627.

66. Mehrabani M, Ghassemi N, Sajjadi E, Ghannadi A, Shams-Ardakani M (2005). Main phenolic compound of petals of Echium amoenum Fisch. and C. A. Mey., a famous medicinal plant of Iran. DARU. 13/2: 65-69.

67. Mishra LC, Singh BB, Dagenais S (2000). Scientific basis for the therapeutic use of Withania somnifera (ashwagandha): a review. Altern Med Rev. 5/4: 334346.

68. Morgan A, Stevens J (2010). Does Bacopa monnieri improve memory performance in older persons? Results of a randomized, placebo-controlled, doubleblind trial. J Altern Complement Med. 16/7: 753-759.

69. Movafegh A, Alizadeh R, Hajimohamadi F, Esfehani F, Nejatfar M (2008). Preoperative oral Passiflora incarnata reduces anxiety in ambulatory surgery patients: a double-blind, placebo-controlled study. Anesth Analg. 106/6: 1728-1732.

70. Napoletano M, Fraire C, Santangelo F, Moriggi E (2001). Mesembrine is an inhibitor of PDE4 that follows the structure-activity relationship of rolipram. Chem Prepr Arch. p. 303-308. 
71. Ngan A, Conduit R (2011). A double-blind, placebocontrolled investigation of the effects of Passiflora incarnata (passionflower) herbal tea on subjective sleep quality. Phytother Res. 25/8: 1153-1159.

72. Onusic GM, Nogueira RL, Pereira AM, Viana MB (2002). Effect of acute treatment with a wateralcohol extract of Erythrina mulungu on anxietyrelated responses in rats. Braz J Med Biol Res. 35/4: 473-477.

73. Patil AP, Patil VR (2011). Clitoria ternatea Linn.: An Overview. IJPR. 3/1: 20-23.

74. Patnala S, Kanfer I (2009). Investigations of the phytochemical content of Sceletium tortuosum following the preparation of "Kougoed" by fermentation of plant material. J Ethnopharmacol. 121/1: 86-91.

75. Patočka J (2009). Mulungu - anxiolytikum z Amazonského deštného pralesa. Psychiatrie. 13/2-3: 89-91.

76. Patočka J, Strunecká A (2001). Kava-kava - využití v psychiatrii. Psychiatrie. 5/3: 182-186.

77. Peng WH, Hsieh MT, Lee YS, Lin YC, Liao J (2000). Anxiolytic effect of seed of Ziziphus jujuba in mouse model of anxiety. J Ethnopharmacol. 72/3: 435-441.

78. Peng W, Han T, Wang Y, Xin WB, Zheng ChJ, Qin LP (2011). Chemical constituents of the aerial part of Atractylodes macrocephala. Chem Nat Comp. 46/6: 959-960.

79. Plotkin MJ (1994). Tales of a Shaman's Apprentice: An Ethnobotanist Searches for New Medicines in the Amazon Rain Forest. Penguin Books USA. 328 p.

80. Plotkin MJ (2001). Medicine Quest: In Search of Nature's Healing Secrets. Penguin Books USA. 240 p.

81. Polívka F (1908). Užitkové a pamětihodné rostliny cizích zemí. Reprint z roku 1908, Volvox globator Praha 1996. $646 \mathrm{~s}$.

82. Potterat O, Hamburger M (2007). Morinda citrifolia (Noni) Fruit - Phytochemistry, Pharmacology, Safety. Planta Med. 73/3: 191-199.

83. Qiang LQ, Wang CP, Wang FM, Pan Y, Yi LT, Zhang X, Kong LD (2009). Combined administration of the mixture of honokiol and magnolol and ginger oil evokes antidepressant-like synergism. Arch Pharm Res. 32/9: 1281-1292.

84. Rabbani M, Sajjadi SE, Vaseghi G, Jafarian A (2004). Anxiolytic effects of Echium amoenum on the elevated plus-maze model of anxiety in mice. Fitoterapia. 75/5: 457-464.

85. Rabbani M, Sajjadi SE, Khalili S (2011). A Lack of tolerance to the anxiolytic action of Echium amoenum. RPS. 6/2: 101-106.

86. Rataj K (1983). Akvaristika začíná u rostlin. Svépomoc Praha. 105 s.

87. Rätsch C (2005). The Encyclopedia of Psychoactive Plants: Ethnopharmacology and Its Applications. Park Street Press. 944 p.

88. Ribeiro MD, Onusic GM, Poltronieri SC, Viana MB (2006). Effect of Erythrina velutina and Erythrina mulung $u$ in rats submitted to animal models of anxiety and depression. Braz J Med Biol Res. 39/2: 263-270.

89. Sairam K, Dorababu M, Goel RK, Bhattacharya SK (2002). Antidepressant activity of standardized extract of Bacopa monniera in experimental models of depression in rats. Phytomedicine. 9/3: 207-211.

90. Saiyudthong S, Marsden CA (2011). Acute Effects of Bergamot Oil on Anxiety-related Behaviour and
Corticosterone Level in Rats. Phytother Res. 25/6: 858-862.

91. Saraf MK, Prabhakar S, Anand A (2010). Neuroprotective effect of Bacopa monnieri on ischemia induced brain injury. Pharmacol Biochem Behav. 97/2: 192-197.

92. Sarris J, Kavanagh DJ (2009). Kava and St. John's Wort: Current Evidence for Use in Mood and Anxiety Disorders. J Altern Complement Med. 15/8: 1-10.

93. Sarris J, LaPorte E, Schweitzer I (2011). Kava: a comprehensive review of efficacy, safety, and psychopharmacology. Aust N Z J Psychiatry. 45/1: 27-35.

94. Sayyah M, Sayyah M, Kamalijenad M (2006). A preliminary randomized double blind clinical trial on the efficacy of aqueous extract of Echium amoenum in the treatment of mild to moderate major depression. Prog Neuropsychopharmacol Biol Psych. 30/1: 166-169.

95. Sayyah M, Boostani H, Pakseresht S, Malaieri A (2009). Efficacy of aqueous extract of Echium amoenum in treatment of obsessive-compulsive disorder. Prog Neuro-Psychoph. 33/8: 1513-1516.

96. Seidemann J (2005). World Spice Plants. Economic Usage, Botany, Taxonomy. Springer-Verlag Berlin, Heidelberg, New York. 591 p.

97. Shikha S, Nidhi M, Upama M (2009). Bacopa monniera - A Future Perspective. IJPSDR. 1/3: 154-157.

98. Shinomol GK, Muralidhara, Bharath MM (2011). Exploring the Role of "Brahmi" (Bacopa monnieri and Centella asiatica) in Brain Function and Therapy. Recent Pat Endocr Metab Immune Drug Discov. 5/1: 33-49.

99. Singh YN (ed.) (2004). Kava from Ethnology to Pharmacology. Medicinal and Aromatic Plants Industrial Profiles. CRC Press. $167 \mathrm{p}$.

100. Singhuber J, Baburin I, Kählig H, Urban E, Kopp B, Hering S (2012). GABA(A) receptor modulators from Chinese herbal medicines traditionally applied against insomnia and anxiety. Phytomedicine. 19/34: 334-340.

101. Smith MT, Crouch NR, Gericke N, Hirst M (1996) Psychoactive constituents of the genus Sceletium N. E. Br. and other Mesembryanthemaceae: a review. J Ethnopharmacol. 50/3: 119-130.

102. Smith MT, Field, CR, Crouch NR, Hirst M (1998). The distribution of mesembrine alkaloids in selected taxa of the Mesembryanthemaceae and their modification in the Sceletium derived 'Kougoed'. Pharm Biol. 36/3: 173-179.

103. Sonavane GS, Sarveiya VP, Kasture VS, Kasture SB (2002). Anxiogenic activity of Myristica fragrans seeds. Pharmacol Biochem Behav. 71/1-2: 239-244.

104. Soulimani R, Younos C, Jarmouni S, Bousta D, Misslin R, Mortier F (1997). Behavioural effects of Passiflora incarnata $\mathrm{L}$. and its indole alkaloid and flavonoid derivatives and maltol in the mouse. $\mathrm{J}$ Ethnopharmacol. 57/1: 11-20.

105. Stevens PF (2008). Angiosperm Phylogeny Website Version 9, June 2008. http://www.mobot.org/ MOBOT/research/Apweb.

106. Stough C, Lloyd J, Clarke J, Downey L, Hutchison CW, Rodgers T, Nathan PJ (2001). The chronic effects of an extract of Bacopa monniera (Brahmi) 
on cognitive function in healthy human subjects. Psychopharmacology. 156/4: 481-484.

107. Tabassum I, Siddiqui ZN, Rizvi SJ (2010). Effects of Ocimum sanctum and Camellia sinensis on stressinduced anxiety and depression in male albino Rattus norvegicus. Indian J Pharmacol. 42/5: 283-288.

108. Taranalli AD, Cheeramkuczhi TC (2000). Influence of Clitoria ternatea on memory and central cholinergic activity in rats. Pharm Biol. 38/1: 51-56.

109. Taur DJ, Patil RY (2011). Evaluation of antiasthmatic activity of Clitoria ternatea L. roots. J Ethnopharmacol. 136/2: 374-376.

110. Tripathi M, Pandey MB, Jha RN, Pandey VB, Tripathi PN, Singh JP (2001). Cyclopeptide alkaloids from Zizyphus jujuba. Fitoterapia. 72/5: 507-510.

111. Uabundit N, Wattanathorn J, Mucimapura S, Ingkaninan K (2010). Cognitive enhancement and neuroprotective effects of Bacopa monnieri in Alzheimer's disease model. J Ethnopharmacol. 127/1: 26-31.

112. Valíček P (ed.) (2002). Užitkové rostliny tropů a subtropů. 2. vyd., Praha: Academia. 486 s.

113. van Wyk BE, Wink M (2005). Medicinal plants of the world. Timber Press, Portland, Oregon, USA. 480 p.

114. Vasconcelos SM, Rebouças Oliveira G, Mohana de Carvalho M, Rodrigues AC, Rocha Silveira E, Maria França Fonteles M, Florenço Sousa FC, Barros Viana GS (2003). Antinociceptive activities of the hydroalcoholic extracts from Erythrina velutina and Erythrina mulungu in mice. Biol Pharm Bull. 26/7: 946-949.

115. Vasconcelos SM, Lima NM, Sales GT, Cunha GM, Aguiar LM, Silveira ER, Rodrigues AC, Macedo DS, Fonteles MM, Sousa FC, Viana GS (2007). Anticonvulsant activity of hydroalcoholic extracts from Erythrina velutina and Erythrina mulungu. J Ethnopharmacol. 110/2: 271-274.

116. Vishwakarma SL, Pal SC, Kasture VS, Kasture SB (2002). Anxiolytic and antiemetic activity of Zingiber officinale. Phytother Res. 16/7: 621-626.

117. Votava M, Agová V, Kršiak M (2005). Mechanismy účinku anxiolytik. Psychiatr prax. 6/3: 131-133.

118. Wang MY, West BJ, Jensen CJ, Nowicki D, Su C, Palu AK, Anderson G (2002). Morinda citrifolia (Noni): A literature review and recent advances in Noni research. Acta Pharmacol Sin. 23/12: 1127-1141.

119. Wei XY, Yang JY, Wang JH, Wu CF (2007). Anxiolytic effect of saponins from Panax quinquefolium in mice. J Ethnopharmacol. 111/3: 613-618.

120. White B (2007). Ginger: An Overview. Am Fam Phys. 75/11: 1689-1691.

121. WHO (World Health Organisation) (2007). WHO Monographs on Selected Medicinal Plant. Vol. 3. 376 p.
122. Wijeweera P, Arnason JT, Koszycki D, Merali Z (2006). Evaluation of anxiolytic properties of Gotukola (Centella asiatica) extracts and asiaticoside in rat behavioral models. Phytomedicine. 13/9-10: $668-676$.

123. Williamson EM (2003). Potter's Herbal Cyclopaedia. The autoritative reference work on plants with a known medicinal use. Saffron Walden, The C. W. Daniel Company Limited. 503 p.

124. Wink M, van Wyk B-E (2008). Mind-altering and poisonous plants of the world. Timber Press, Portland, London. $464 \mathrm{p}$.

125. Wohlmuth H, Penman KG, Pearson T, Lehmann RP (2010). Pharmacognosy and Chemotypes of Passionflower (Passiflora incarnata L.). Biol Pharm Bull. 33/6: 1015-1018.

126. Wu, ZY, Raven PH, Hong D (eds.) (2011). Flora of China Vol. 20-21. Asteraceae. Science Press \& Missouri Botanical Garden Press. 992 p.

127. Xu Ch, Teng J, Chen W, Ge Q, Yang Z, Yu Ch, Yang Z, Jia W (2010). Protopanaxadiol, an active ginseng metabolite, exhibits strong antidepressantlike effect. Prog Neuropsychopharmacol Biol Psych. 34/8: 1402-1411.

128. Yi LT, Xu Q, Li YCh, Yang L, Kong LD (2009). Antidepressant-like synergism of extracts from magnolia bark and ginger rhizome alone and in combination in mice. Prog Neuropsychopharmacol Biol Psych. 33/4: 616-624.

129. Younos C, Rolland A, Fleurentin J, Lanhers MC, Misslin R, Mortier F (1990). Analgesic and Behavioural Effects of Morinda citrifolia. Planta Med. 56/5: 430-434.

130. Zheng CJ, Qin LP (2007). Chemical components of Centella asiatica and their bioactivities. J Chin Integr Med / Zhong Xi Yi Jie He Xue Bao. 5/3: 348-351.

131. Zhengyi W, Raven P (eds.) (1998). Flora of China Vol. 18. Scrophulariaceae through Gesneriaceae. Missouri Botanical Garden. 449 p.

132. Zhengyi W, Raven P (eds.) (2005). Flora of China. Vol. 14. Apiaceae through Ericaceae. Missouri Botanical Garden Press. 581 p.

133. Zhengyi W, Raven P (eds.) (2007). Flora of China. Vol. 13. Clusiaceae through Araliaceae. Missouri Botanical Garden Press. 548 p.

134. Zhengyi W, Raven P, Deyuan H (eds.) (2011). Flora of China.Vol. 19. Cucurbitaceae through Valerianaceae with Annonaceae and Berberidaceae. Science Press (Beijing), Missouri Botanical Garden Press. 884 p.

\section{Zdeňka Navrátilová navratil@natur.cuni.cz}

